\title{
Postruminal infusions of amino acids or glucose affect metabolisms of splanchnic, mammary, and other peripheral tissues and drive amino acid use in dairy cows
}

\author{
C. Omphalius, ${ }^{1,2}$ S. Lemosquet, ${ }^{1}$ D. R. Ouellet, ${ }^{3}$ L. Bahloul, ${ }^{2}$ and H. Lapierre ${ }^{3 *}$ \\ ${ }^{1}$ PEGASE, INRA, Agrocampus Ouest, 35590 Saint Gilles, France \\ ${ }^{2}$ Adisseo France S.A.S., 10, Place du General de Gaulle, 92160 Antony, France \\ ${ }^{3}$ Agriculture and Agri-Food Canada, Sherbrooke, QC, Canada J1M 0C8
}

\section{ABSTRACT}

Effects of AA and glucose infusions on efficiency of use of essential AA (EAA) were studied according to a $2 \times 2$ factorial using 5 multicatheterized cows in a 4 $\times 4$ Latin square plus one cow, with 2 -wk periods. The diet provided $87 \%$ of energy and $70 \%$ of metabolizable protein requirements, and the 4 treatments were abomasal infusions of (1) water, (2) an AA mixture with a casein profile $(695 \mathrm{~g} / \mathrm{d}),(3)$ glucose $(1,454 \mathrm{~g} / \mathrm{d})$, or (4) a combination of AA and glucose infusions. Milk samples were collected on the last 6 milkings. On d 14, 6 blood samples were collected from arterial, and portal, hepatic, and mammary venous vessels. Splanchnic plasma flow was calculated by dilution of $p$-aminohippurate and mammary flow by the Fick principle using Phe + Tyr. The net flux of AA across tissues [splanchnic, i.e., portal-drained viscera (PDV) + liver, and mammary gland] was calculated as the efflux minus the influx across that tissue. The efficiency of EAA was calculated as the sum of exported true proteins [milk protein yield (MPY), scurf, and metabolic fecal protein] multiplied by their respective AA profile and divided by the predicted AA supply minus AA endogenous urinary loss. In addition, catabolism was estimated for each tissue: AA supply - (portal net flux + metabolic fecal protein) for the PDV; - hepatic net flux for the liver; splanchnic net flux $-(-$ mammary net flux + scurf $)$ for the other peripheral tissues; and -mammary net flux - milk for the mammary gland. The MIXED procedure (SAS Institute Inc., Cary, NC) was used with cow as a random effect. No AA $\times$ glucose interaction existed for most of the measured parameters. With infusions of AA and glucose, MPY increased by 17 and $14 \%$, respectively. The decreased efficiency of EAA-N with AA infusion resulted from increased EAA-N in MPY smaller than

Received July 11, 2019.

Accepted November 6, 2019.

*Corresponding author: helene.lapierre@canada.ca the increased EAA-N supply and was accompanied by increased liver catabolism of His + Met + Phe (representing group $1 \mathrm{AA}$ ) and increased mammary and PDV catabolisms of group 2 AA-N (Ile, Leu, Lys, and Val). In contrast, the increased efficiency of EAA-N with glucose infusion, resulting from increased EAA-N in MPY with no change in EAA-N supply, was accompanied by decreased mammary catabolism of group 2 AA-N and hepatic catabolism of His + Met + Phe. No mammary catabolism of His, Met, and Phe existed in all treatments, as indicated by the mammary uptake to milk output ratio close to one for these EAA. Therefore, the mammary gland contributes significantly to variations of efficiency of group $2 \mathrm{AA}-\mathrm{N}$ through variations of AA catabolism, in response to both AA and glucose supplies, whereas additional PDV catabolism was observed with increased AA supply. Partition of AA use between tissues allows to delineate their anabolic or catabolic fate across tissues and better understand changes of efficiency of EAA in response to protein and energy supplies.

Key words: protein, energy, net flux, catabolism, efficiency

\section{INTRODUCTION}

To face the challenge of increasing dietary $\mathrm{N}$ efficiency (milk $\mathrm{N} / \mathrm{N}$ intake) in lactating dairy cows without a detrimental effect on milk true protein yield (MPY), researcher have already identified several options. Balancing diets for AA (Haque et al., 2012, 2015; Lee et al., 2012), increasing $\mathrm{NE}_{\mathrm{L}}$ supply (Raggio et al., 2006b; Rius et al., 2010b), or changing the source of energy (Cantalapiedra-Hijar et al., 2014b; Nichols et al., 2019) increased the efficiency of use of MP, referred to as efficiency through the text. Although variations of efficiency of MP under various nutritional conditions have been characterized, variations of efficiency of individual EAA have not been yet thoroughly examined in response to changes of energy supply, combined or not 
with alteration of AA supply. A meta-analysis reported a decreased efficiency of EAA with increased AA supply, with variations of efficiency of EAA among AA (Doepel et al., 2004). Similarly, increasing Lys or Met supply by feeding a rumen-protected form decreased their respective efficiency of use for milk protein secretion (Lee et al., 2015). Nevertheless, effect of $\mathrm{NE}_{\mathrm{L}}$ or the interaction between $\mathrm{NE}_{\mathrm{L}}$ and $\mathrm{AA}$ supplies on efficiency of EAA need to be determined to better balance dairy rations for individual EAA.

Indeed, $\mathrm{NE}_{\mathrm{L}}$ supply may affect $\mathrm{AA}$ metabolism due to the energy cost of protein synthesis (Lobley, 1990). It was also proposed that energy supply might affect AA use for gluconeogenesis (Cant et al., 1993). In fact, postrumen infusion of glucose or rumen infusion of propionate increased efficiency of group 1 AA (i.e., His, Met, Phe, Trp, and Tyr) with increased mammary uptake and secretion in milk protein and no change in AA supply (Lemosquet et al., 2010a). In dairy cows fed 3 levels of MP, efficiency of EAA, calculated as the ratio of AA in MPY relative to net portal absorption, decreased with increased MP supply (Raggio et al., 2004). For Met, Phe, and Tyr, the decreased efficiency was linked to increased hepatic removal, whereas for group 2 AA (i.e., Ile, Leu, Lys, and Val), it was related to an increased excess of mammary uptake relative to MPY, indicating an increased mammary use of these AA not linked to their direct incorporation into MPY. Moreover, abomasal glucose infusion (Huhtanen et al., 2002; Nichols et al., 2016) decreased branched-chain AA (BCAA) plasma concentration with no effect on their mammary uptake, suggesting increased use of the BCAA by other peripheral tissues such as muscle or splanchnic tissues, or both.

These observations indicate a different partition of AA use between tissues and an alteration between anabolic or catabolic fate within tissue in response to changes in protein or energy supplies. This raises the question of how altering supplies of AA or energy (through glucose infusion), or both, affects the coordination of AA use by splanchnic, mammary, and other peripheral tissues for anabolic or catabolic purposes and how these variations affect whole-body efficiency of EAA. We hypothesized that the decreased efficiency of EAA observed with increased AA supply and increased efficiency of EAA with glucose supply could be explained through different mechanisms, affecting differently the partition of groups of AA between tissues and the partition between anabolism and catabolism within tissue. To our knowledge, no studies yet report the effect of variations of levels of protein and energy supplies on splanchnic and mammary net fluxes of $\mathrm{AA}$ and relate these measured fluxes to predicted AA supply in lactating dairy cows. Consequently, this knowledge on the use (export or catabolism) of AA by various tissues under different nutritional conditions will help to determine factors affecting the efficiency of EAA and therefore improve prediction of individual efficiency of EAA. This information could be used in feeding systems to either improve, for a given diet, the prediction of MPY or to identify which AA are potentially in short supply.

\section{MATERIALS AND METHODS}

\section{Cows and Surgery}

The trial was carried out at the Sherbrooke Research and Development Center of Agriculture and Agri-Food Canada (QC, Canada). Five Holstein cows in second lactation had been fitted before calving with a rumen cannula (Galindo et al., 2011). Approximately $8 \mathrm{wk}$ after calving, the cows were surgically implanted with catheters: 1 in the abomasum (Doepel et al., 2006), 1 in a mesenteric artery, 2 in mesenteric veins, 1 in the portal vein, and 1 in a hepatic vein (Huntington et al., 1989). During the surgery, the right carotid artery was also raised to a subcutaneous position to provide access to arterial blood if necessary.

At the initiation of the study, the cows averaged (mean \pm SD) $158 \pm 13$ DIM and $655 \pm 53 \mathrm{~kg}$ of BW. Before and throughout the study, cows were housed in individual tie stalls and had access to fresh water. The experimental protocol was approved by the Institutional Animal Care Committee of the Sherbrooke Research and Development Center, and animals were treated according to the guidelines of the Canadian Council on Animal Care (1993).

\section{Experimental Design, Treatments, Feeding, and Milking}

Throughout the study, cows received the same experimental diet (Table 1). Based on the cows' performance the week before the initiation of the project $(30.8 \mathrm{~kg}$ of milk/d at $3.2 \% \mathrm{CP}$ and $3.7 \%$ fat and an average DMI of $18.0 \mathrm{~kg} / \mathrm{d}$ ), the experimental diet was designed to provide $87 \%$ of $\mathrm{NE}_{\mathrm{L}}$ and $70 \%$ of $\mathrm{MP}$ requirements (NRC, 2001). Two factors, infusion of AA or infusion of glucose, were tested in a $2 \times 2$ factorial arrangement. The 4 treatments were continuous abomasal infusion of (1) water $(\mathbf{C t r l}),(2)$ an AA mixture with a casein profile $\left(\mathbf{A A}_{\mathbf{C N}} ; 695 \mathrm{~g} / \mathrm{d}\right.$, Table 2$)$, (3) glucose $\left(\mathbf{E}_{\mathbf{G l c}} ; 1,600\right.$ $\mathrm{g} / \mathrm{d}$ glucose monohydrate, yielding $1,454 \mathrm{~g} / \mathrm{d}$ glucose), and (4) a combination of AA mixture and glucose at the same doses $\left(\mathbf{A} \mathbf{A}_{\mathbf{C N}}+\mathbf{E}_{\mathrm{Glc}}\right)$. The rates of infusion of AA or glucose were selected so that the diet plus the infusions would meet $\mathrm{MP}$ or $\mathrm{NE}_{\mathrm{L}}$ requirements, respec- 
Table 1. Composition of the experimental diet and chemical composition of the feed ingredients

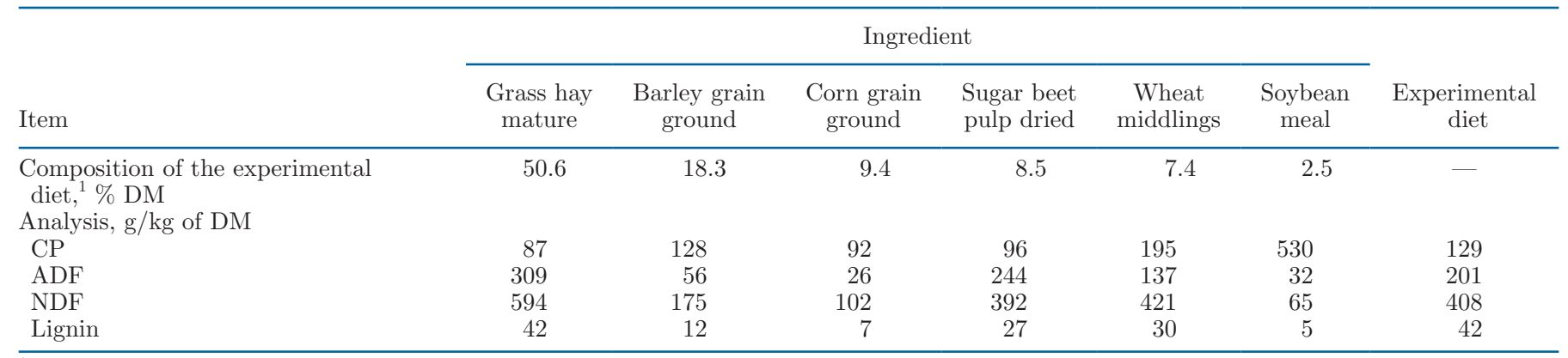

${ }^{1}$ The diet also contained a mineral and vitamin premix $(2.6 \% \mathrm{DM})$ and urea $(0.6 \% \mathrm{DM})$.

tively (NRC, 2001). The cows received the 4 treatments in a $4 \times 4$ Latin square design, balanced for residual effect, plus one cow, with 2-wk experimental periods. The 4 treatments were delivered $(6 \mathrm{~kg} / \mathrm{d})$ into the abomasum by means of peristaltic pumps. The AA solutions were diluted daily from a stock solution prepared every 2 or $3 \mathrm{~d}$, whereas the glucose solutions were prepared daily. Two cows received treatments through an abomasal tube installed via the rumen cannula (Gressley et al., 2006) because the abomasal catheters did not function well.

To minimize refusals, cows were offered $98 \%$ of ad libitum intake measured the week before the initiation of the project. The quantity of the ration offered and orts (when present) were weighed every day. To minimize postprandial variations of metabolite concentrations and transorgan fluxes, feed was supplied every $2 \mathrm{~h}$ in equal portions on even hours from automated feeders

Table 2. Infusion rate of AA

\begin{tabular}{lc}
\hline AA & Infusion rate, $\mathrm{g} / \mathrm{d}$ \\
\hline EAA & 25.0 \\
Arg & 18.6 \\
His & 33.7 \\
Ile & 63.0 \\
Leu & 52.9 \\
Lys & 19.6 \\
Met & 72.0 \\
Phe & 29.3 \\
Thr & 8.1 \\
Trp & 38.3 \\
Val & \\
NEAA & 20.8 \\
Ala & 20.8 \\
Asp & 25.7 \\
Asn & 2.7 \\
Cys & 51.6 \\
Glu & 89.5 \\
Gln & 12.6 \\
Gly & 71.7 \\
Pro & 38.6 \\
Ser & \\
\hline
\end{tabular}

to cows milked twice daily at 0630 and $1830 \mathrm{~h}$. Milk production was recorded at each milking.

\section{Sampling and Laboratory Analyses}

Feed and Milk. The concentrate was made in one batch before the initiation of the trial. Samples of ingredients used for the concentrate were then collected. Samples of dry hay and concentrate were collected every week to determine the DM concentration by drying at $80^{\circ} \mathrm{C}$ for $48 \mathrm{~h}$ and pooled by period to be analyzed for chemical composition: $\mathrm{CP}, \mathrm{ADF}, \mathrm{NDF}$, and lignin as described by Martineau et al. (2007). The analyses of the pooled samples of concentrate were used to confirm the values obtained for the raw material, and values for individual feed ingredients were used to calculate the feed value of the diet (NRC, 2001). Milk samples were collected on the last 6 milkings of each period and analyzed for total N, NPN, and noncasein $\mathrm{N}$ according to Raggio et al. (2004).

Blood. On last day of each period, from $0800 \mathrm{~h}$ to the end of the sampling period, sodium $p$-aminohippurate (pAH; $100 \mathrm{~g} / \mathrm{L})$ was continuously infused using a syringe pump into one mesenteric vein, at $12 \mathrm{~g} / \mathrm{h}$, to determine splanchnic plasma flow by dilution. Six sets of blood samples were collected at 0900, 0940, 1020, 1145, 1225 , and $1305 \mathrm{~h}$ from each cow simultaneously from arterial, portal, and hepatic venous catheters. Right after each set of splanchnic sampling, a blood sample was taken from one mammary vein by venipuncture, alternating right and left side at each sampling. Blood was immediately put on ice and centrifuged (12 min, $1,800 \times g$ at $4^{\circ} \mathrm{C}$ ) to yield plasma. Fresh plasma subsamples were immediately used to determine urea-N concentrations, using the diacetyl monoxime method on an automatic analyzer (Technicon Autoanalyzer II, Technicon Instruments Corporation, Tarrytown, NY) according to Huntington (1984). In addition, $1 \mathrm{~g}$ of fresh plasma was added to $0.2 \mathrm{~g}$ of an internal standard solution of labeled AA, as described in Doepel and 
Lapierre (2011). The processed samples were stored at $-80^{\circ} \mathrm{C}$ until they were analyzed for AA concentrations, determined by isotope dilution using GC/MS (model GC 6890-MS 5973, Agilent Technologies, Wilmington, DE) as previously described by Calder et al. (1999) and Doepel and Lapierre (2011). The remainder of the plasma was stored at $-20^{\circ} \mathrm{C}$. Concentrations of $\mathrm{pAH}$ on arterial, portal, and hepatic samples were analyzed after deacetylation of pAH as described by Lobley et al. (1995).

\section{Calculations}

The dietary EAA supply was calculated from the flow of digestible EAA predicted by the NRC (2001) multiplied by correction factors to take into account the incomplete recovery of AA after 24-h hydrolysis of a protein (Lapierre et al., 2019; Table 3). Moreover, we removed from the predicted MP supply and the corrected digestible flow of individual EAA the contribution from duodenal endogenous flow, included in the predicted MP supply and AA digestible flows (NRC, 2001). The contribution of the endogenous duodenal flow to MP supply or AA digestible flow was estimated as 96.1 $+7.45 \times \mathrm{DMI}_{\mathrm{kg} / \mathrm{d}}(\mathrm{g}$ of $\mathrm{CP} / \mathrm{d}$; Lapierre et al., 2016) multiplied by 0.8 to account for intestinal digestibility (NRC, 2001); this flow was then either multiplied by the ratio of true protein (TP) to $\mathrm{CP}$ of gut endogenous proteins of 0.73 (Lapierre et al., 2020) or multiplied by its AA composition (Table 3). Therefore, total supply of individual EAA (diet + infusion, Table 4 ) was the sum of the predicted digestible flow corrected for incomplete recovery with 24 -h hydrolysis minus duodenal endogenous contribution plus the rate of AA infusion when applicable; the digestibility of infused AA was assumed to be $100 \%$. The supplies of EAA were expressed in their hydrated form. Because the sum of the hydrated AA supply is roughly $15 \%$ higher than when expressed as protein, because each AA is losing one molecule of water for each peptide bond during protein synthesis, total MP supply (Table 4) was calculated as predicted MP supply (NRC, 2001) minus duodenal endogenous contribution to MP, as detailed above, plus the rate of AA infusion (expressed in their anhydrous form, equivalent to $600 \mathrm{~g} / \mathrm{d}$ of MP). From herein to the end of the text, supply of MP or AA digestible flow will refer to their respective supply corrected as defined above. The NEAA supply, not predicted by the NRC (2001), was calculated as the difference between MP supply expressed in hydrated form of AA (i.e., MP $\times 1.15)$ and total EAA supply. The total $\mathrm{NE}_{\mathrm{L}}$ supply (diet + infusion, Table 4) was estimated by adding dietary $\mathrm{NE}_{\mathrm{L}}$ supply predicted by the NRC (2001) and $\mathrm{NE}_{\mathrm{L}}$ from infusion of glucose [Glc; $2.75 \mathrm{Mcal} / \mathrm{kg}$ of infused glucose (Armstrong and Blaxter, 1961) = $4.0 \mathrm{Mcal} / \mathrm{d}]$. Using the INRA feeding system (INRA, 2018), the experimental diet supplied $( \pm \mathrm{SD}) 84 \pm 0.4$ $\mathrm{g} / \mathrm{kg}$ of DM of protein digestible in the small intestine (PDI, equivalent to MP) and $1.58 \pm 0.01 \mathrm{Mcal}$ of $\mathrm{NE}_{\mathrm{L}} /$ $\mathrm{kg}$ of DM.

The AA composition of the milk protein (Table 3) was estimated for each cow $\times$ period from the measured proportions of casein and whey proteins relative to TP, using the AA composition of each family of protein reported by Farrell et al. (2004). Adapted from Lapierre et al. (2020), the following milk protein fractions were assumed to be constant (\% TP): lactoferrin $0.21 \%$, albumin 1.04\%, IgG1 1.64\%, IgGA $0.04 \%$, IgG2 0.18\%, and IgM $0.33 \%$. Total casein and whey protein fractions (\% of TP) measured for each cow $\times$ period were used

Table 3. Correction factors and AA composition of proteins used in the calculation of the individual AA supplies and efficiencies

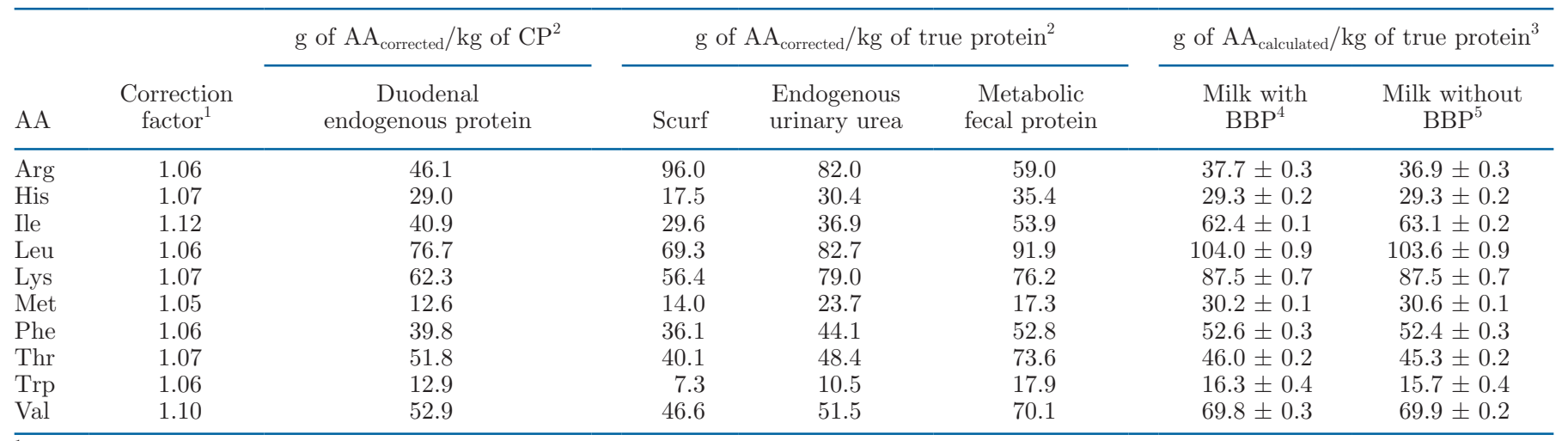

\footnotetext{
${ }^{2}$ From Lapierre et al. (2020).

${ }^{3}$ Average of 19 milk compositions (cow $\times$ period); see the Calculations section for details.

${ }^{4}$ Including blood-borne proteins (BBP; mean $\left.\pm \mathrm{SD}\right)$.

${ }^{5}$ Excluding BBP (mean $\left.\pm \mathrm{SD}\right)$.
}

${ }^{1}$ Corrections factors used to account for incomplete recovery of AA with 24-h hydrolysis of proteins, from Lapierre et al. (2019). 
Table 4. Protein, AA, and energy supplies from the experimental diet and infusions

\begin{tabular}{|c|c|c|c|c|c|c|c|c|}
\hline Item & \multicolumn{4}{|c|}{ Treatment $^{1}$} & $\mathrm{SEM}^{2}$ & \multicolumn{3}{|c|}{$P$-value ${ }^{3}$} \\
\hline DMI, kg/d & 17.9 & 17.9 & 17.9 & 17.9 & 0.83 & 0.28 & 0.82 & 0.47 \\
\hline $\mathrm{N}$ intake ${ }^{5} \mathrm{~g} / \mathrm{d}$ & 365 & 462 & 367 & 463 & 17.0 & $<0.01$ & 0.41 & 0.81 \\
\hline MP supply, ${ }^{6} \mathrm{~g} / \mathrm{d}$ & 1,302 & 1,901 & 1,304 & 1,899 & 176.1 & $<0.01$ & 0.78 & 0.30 \\
\hline \multicolumn{9}{|l|}{ EAA digestible flow, ${ }^{7} \mathrm{~g} / \mathrm{d}$} \\
\hline Leu & 118 & 181 & 118 & 180 & 5.6 & $<0.01$ & 0.23 & 0.21 \\
\hline Lys & 94 & 147 & 95 & 147 & 4.2 & $<0.01$ & 0.55 & 0.01 \\
\hline Met & 27 & 47 & 27 & 47 & 1.2 & $<0.01$ & 0.55 & 0.15 \\
\hline Phe & 70 & 142 & 70 & 142 & 3.4 & $<0.01$ & 0.34 & 0.67 \\
\hline Thr & 71 & 100 & 71 & 100 & 3.2 & $<0.01$ & 0.66 & 0.24 \\
\hline Val & 82 & 121 & 82 & 120 & 3.7 & $<0.01$ & $<0.01$ & $<0.01$ \\
\hline
\end{tabular}

${ }^{1} \mathrm{Ctrl}=$ water infusion; $\mathrm{AA}_{\mathrm{CN}}=695 \mathrm{~g} / \mathrm{d}$ AA mixture with casein profile infusion; $\mathrm{E}_{\mathrm{Glc}}=1,454 \mathrm{~g} / \mathrm{d}$ glucose infusion; $\mathrm{AA}_{\mathrm{CN}}+\mathrm{E}_{\mathrm{Glc}}=$ combination of AA mixture and glucose infusion.

${ }^{2} \mathrm{SEM}$ given for $\mathrm{n}=4$.

${ }^{3}$ Probability values correspond to the effect of AA (without vs. with AA infusion), Glc (without vs. with glucose infusion), and AA $\times$ Glc interaction.

${ }^{4} \mathrm{NE}_{\mathrm{L}}$ supply from the NRC (2001) + glucose infusion; see the Calculations section for details.

${ }^{5} \mathrm{~N}$ ingested $+\mathrm{N}$ infused.

${ }^{6} \mathrm{MP}$ supply from the NRC (2001) - MP from endogenous origin + AA infusion; see the Calculations section for details.

${ }^{7}$ Digestive EAA flow estimated from the NRC (2001) corrected for incomplete recovery with a 24-h hydrolysis - AA from MP duodenal endogenous flow + AA infusion, expressed in hydrated form; see the Calculations section for details.

${ }^{8}$ Digestive NEAA flow estimated by difference between MP and EAA supplies, expressed in hydrated form; see the Calculations section for details.

assuming (1) the following casein distribution (\% of casein): $42.7 \% \alpha_{\mathrm{S}_{1}} \mathrm{CN}, 9.2 \% \alpha_{\mathrm{S} 2}-\mathrm{CN}, 37.5 \% \beta-\mathrm{CN}$, and $10.5 \% \mathrm{k}-\mathrm{CN}$ and (2) the following distribution within the remaining whey protein once the fixed contribution of lactoferrin + albumin + Ig was excluded: $72.8 \%$ $\alpha$-LA and $27.2 \% \beta$-LG. Blood-borne proteins were the sum of albumin and Ig and represented $3.23 \%$ of milk TP. Milk protein output was estimated using MPY measured during the last 6 milkings of each period and the AA composition calculated as previously described. The AA composition of milk used to calculate mammary plasma flow excluded blood-borne proteins to consider only proteins synthesized in the mammary gland, whereas the AA composition of milk used to calculate whole-body efficiency included all protein fractions (Table 3).

Mammary plasma flow was determined using the Fick principle based on Phe + Tyr as internal markers (Cant et al., 1993), assuming no mammary oxidation of Phe + Tyr (Lemosquet et al., 2010b). Portal and total splanchnic plasma flows were calculated as infusion rate of $\mathrm{pAH}$ divided by average portal- or hepatic-arterial concentration difference of pAH. Arterial hepatic plasma flow was calculated as splanchnic minus portal plasma flow. Hepatic influx of AA was calculated as (portal plasma flow $\times$ portal concentration $)+($ arterial plasma flow $\times$ arterial concentration). The net fluxes of AA metabolites across portal-drained viscera (PDV), splanchnic tissues, and mammary gland were calculated by multiplying the average veno-arterial (VA) plasma concentration difference by their respective plasma flow. The net flux of urea was calculated similarly but using plasma water concentration [plasma concentration/ (1 - DM of plasma)] and blood water flow, assuming 7 and $12 \%$ DM in plasma and blood, respectively, as previously described (Doepel et al., 2007). The hepatic net flux was calculated as splanchnic minus portal net flux. Negative values of net flux indicate net removal, whereas positive values indicate net release across the studied tissue. When a net removal was observed across the liver or the mammary gland, fractional removal was calculated as -(net flux divided by total influx).

Whole-body efficiency of MP assigned the same efficiency to all proteins exported, excluding nonprotein endogenous urinary losses (EUL), to which an efficiency of one is assigned (INRA, 2018; Lapierre et al., 2020). The efficiency of MP was therefore estimated as follows:

$$
\begin{gathered}
\text { efficiency of MP }=(\text { MPY }+ \text { MFP }+ \text { scurf }) / \\
(\text { MP supply }- \text { EUL })
\end{gathered}
$$


where MP supply is as previously detailed; MPY was observed; and metabolic fecal protein (MFP), scurf proteins, and EUL were calculated as described by Lapierre et al. (2020).

Individual EAA efficiencies were calculated following the same pattern:

$$
\begin{gathered}
\text { efficiency of EAA }=(\mathrm{MPY} \times[\mathrm{EAA}] \text { milk } \\
+\mathrm{MFP} \times[\mathrm{EAA}] \mathrm{MFP}+\mathrm{scurf} \times[\mathrm{EAA}] \mathrm{scurf}) / \\
(\mathrm{EAA} \text { digestible flow }-\mathrm{EUL} \times[\mathrm{EAA}] \mathrm{EUL}),
\end{gathered}
$$

where MPY, MFP, and scurf are as described for efficiency of MP and AA composition is as detailed by Lapierre et al. (2020) except for milk, which was calculated as described earlier (Table 3 ). Both equations assume no protein accretion in conceptus or other tissues. For EUL, briefly, the EAA export is related only to endogenous urea excretion using AA composition of empty body, plus 3-methyl-His excretion added for His, and creatinine and creatine excretion added for Arg. The NEAA-N in protein exported were estimated as the difference between $\mathrm{TP} \times 1.15$ and EAA-N exported, and the efficiency of NEAA-N was estimated as the ratio of NEAA-N in proteins exported and NEAA-N supply previously described minus NEAA-N in EUL.

Potential catabolism of MP and groups of AA by different tissues were calculated based on predicted supply, proteins or AA exported (observed or predicted), and measured net fluxes across tissues. First, the estimated digestible flow not used to support MFP and not recovered into portal circulation was considered as catabolism by PDV. Therefore,

$$
\begin{aligned}
& \text { PDV catabolism }=\text { digestible flow } \\
& -(\text { portal net flux }+\mathrm{MFP}) .
\end{aligned}
$$

Then, the hepatic net removal was considered as catabolism when values were negative. Although it is recognized that part of the hepatic removal of AA is used for the synthesis of liver export proteins (Raggio et al., 2007) and therefore not catabolized, the equivalent of this synthesis must be catabolized somewhere or returned to the liver as peptides. However, very limited data are available on the degradation and use of plasma proteins; therefore, we decided to include their catabolism in hepatic catabolism.

Postliver supply of AA not captured by the mammary gland or secreted into scurf proteins was considered as potential catabolism by other peripheral tissues. Therefore, other peripheral tissue catabolism $=$ splanchnic net flux $-(-$ mammary net flux + scurf $)$.
And finally, the mammary uptake not secreted into milk protein was considered as mammary catabolism. Therefore, mammary catabolism $=-$ mammary net flux - milk AA.

\section{Statistical Analyses}

The average intake and milk production and composition data from the last $3 \mathrm{~d}$ of each period were used for the statistical analyses, whereas the daily means of the 6 blood samples collected on the last day were used for plasma concentrations and net flux data. One cow had vaginal infection during her third period $\left(\mathrm{E}_{\mathrm{Glc}}\right.$ treatment), and consequently, data from this cow were deleted for this period. Therefore, $\mathrm{n}=5$ for Ctrl, $\mathrm{AA}_{\mathrm{CN}}$, and $\mathrm{AA}_{\mathrm{CN}}+\mathrm{E}_{\mathrm{Glc}}$ and $\mathrm{n}=4$ for $\mathrm{E}_{\mathrm{Glc}}$. The data were analyzed using the MIXED procedure of SAS ( $\mathrm{v}$ 9.4, SAS Institute Inc., Cary, NC) according to the following statistical model:

$$
\begin{aligned}
Y_{i j k l}=\mu & +\operatorname{cow}_{i}+\operatorname{period}_{j}+\mathrm{AA}_{k}+\mathrm{Glc}_{l} \\
& +(\mathrm{AA} \times \mathrm{Glc})_{k l}+\varepsilon_{i j k l},
\end{aligned}
$$

where $\mu$ was the mean; $Y_{i j k l}$ was the variable dependent on the fixed effects of period ${ }_{j}, \mathrm{AA}_{k}$ (effect of AA infusion), $\mathrm{Glc}_{l}$ (effect of glucose infusion), and their interaction; and $\varepsilon_{i j k l}$ was the residual error that associated $i j k l$ observations. Cow was treated as a random effect. The results are expressed as least squares means with the highest standard error of the means reported. Homogeneity of residues was verified. The significance level was set to $P \leq 0.05$ and the tendency to $0.05<P \leq 0.10$. When the AA and glucose interaction $(\mathrm{AA} \times \mathrm{Glc})$ was significant, the SLICE procedures of SAS (v 9.4, SAS Institute Inc.) was used to test the effect of one factor within the other factor. Student's $t$-test was used to determine whether efficiency of MP, efficiency of EAA, and uptake to milk output ratios were different from one and catabolisms different from zero. In addition, we tested whether the efficiencies were different between EAA, including the factor "EAA" as a repeated measurement. Because the interaction treatment $\times$ EAA was highly significant $(P<0.001)$, the effect of EAA was tested within each treatment and means separated using adjusted Tukey test.

\section{RESULTS}

\section{DMI and Energy and Protein Supplies}

The DMI was not affected by treatments $(P \geq 0.28$; Table 4). Also, as planned, AA infusion increased $(P<$ 
0.01) MP supply (diet + infusion) by $43 \%$ as well as the predicted digestible flow of individual EAA. Interactions of AA $\times$ Glc existed on the predicted digestible flows of a few EAA. However, we considered that these interactions on predicted flows were statistically significant only because of the very limited variations on predicted flows. Predictions (NRC, 2001) were based on DMI, and alterations of DMI were minimal. We therefore assumed that predicted variations of $\pm 1 \mathrm{~g}$ of $\mathrm{AA} / \mathrm{d}$ were not biologically relevant.

\section{Milk Production and Composition}

No AA $\times$ Glc interaction existed $(P \geq 0.11$; Table $5)$ on any of the milk parameters measured. Milk yield increased $(P=0.04)$ with AA infusion, whereas glucose infusion tended to increase $(P=0.07)$ it. Milk TP yield and concentration increased $(P<0.01)$ with infusions of AA or glucose. Milk CP concentration increased ( $P$ $<0.01$ ) with infusions of AA or glucose, whereas the proportion of NPN relative to CP increased $(P<0.01)$ with AA infusion but decreased $(P=0.02)$ with glucose infusion. The proportion of casein relative to TP tended $(P=0.08)$ to decrease with AA infusion.

\section{MP and EAA Whole-Body Efficiencies}

The estimated efficiency of MP decreased $(P<0.01)$ with AA infusion and increased with glucose infusion $(P$ $<0.01$ ), with similar trends for groups of AA (Table 6 ). The individual estimated EAA efficiencies decreased $(P$ $<0.01$ ) with AA infusion, and marked differences among EAA were observed: Phe and Met estimated efficiencies decreased by 42 and $32 \%$, respectively, whereas Val, Ile, and Thr estimated efficiencies decreased by 21, 21, and $19 \%$, respectively. Contrary to AA infusion effect, individual EAA efficiencies increased $(P \leq 0.03)$ with glucose infusion in similar proportions, from 8 to $11 \%$. No significant interaction was observed between AA and glucose infusions on estimated efficiencies. Across all treatments, the efficiency of Arg was the highest, followed by His and Met, whereas the efficiencies of Phe and Thr were the lowest. Indeed, efficiency of Arg was greater than one in Ctrl and $\mathrm{E}_{\mathrm{Glc}}$ treatments, whereas the efficiency of His tended to be greater than one in $\mathrm{E}_{\mathrm{Glc}}$ treatment. All other EAA efficiencies were significantly lower than one, except for His and Met in Ctrl treatment and for Lys and Met in $\mathrm{E}_{\mathrm{Glc}}$ treatment, which were not different $(P>0.10)$ from one.

\section{Plasma Arterial Concentrations of Individual $A A$ and Urea}

No AA $\times$ Glc interaction existed $(P>0.10$; Table 7) on the arterial concentrations of any AA. Infusions of AA increased the arterial concentrations of all EAA $(P \leq 0.02)$, with the exception of a tendency for Trp $(P=0.06)$ and no effect for Thr $(P=0.17)$. Increases averaged from $22 \%$ (Arg) to $69 \%$ (Phe) of Ctrl values. For the NEAA, the AA infusion increased $(P<0.01)$ arterial concentrations of Cit, Orn, and Pro; decreased $(P=0.01)$ Gly; and tended $(P \leq 0.09)$ to decrease arterial concentrations of Ala and Tyr. Overall, the plasma concentrations of total AA-N (TAA-N), EAAN, group 1 AA-N (sum of His, Met, Phe, Trp, and Tyr; Lapierre et al., 2012), HMP-N (sum of His, Met, and Phe), group 2 AA-N (sum of Lys, Ile, Leu, and Val; Mepham, 1982), and BCAA-N (sum of Ile, Leu, and Val) increased $(P<0.01)$ with AA infusion, whereas arterial concentration of NEAA-N was not affected by AA infusion $(P=0.32)$. Because of technical problem, Asn concentrations were not available for one cow for the 4 periods and for one cow for 2 periods; therefore, the sum of NEAA-N does not include Asn. In contrast,

Table 5. Effects of AA and glucose infusions on milk production and composition ${ }^{1}$

\begin{tabular}{|c|c|c|c|c|c|c|c|c|}
\hline Item & \multicolumn{4}{|c|}{ Treatment $^{2}$} & $\mathrm{SEM}^{3}$ & \multicolumn{3}{|c|}{$P$-value ${ }^{4}$} \\
\hline True protein yield, g/d & 722 & 815 & 797 & 956 & 68.1 & $<0.01$ & 0.01 & 0.27 \\
\hline True protein concentration, $\mathrm{g} / \mathrm{kg}$ & 33.9 & 36.7 & 36.3 & 40.0 & 0.87 & $<0.01$ & $<0.01$ & 0.57 \\
\hline Casein, $\%$ of true protein & 81.5 & 80.3 & 81.1 & 81.1 & 0.87 & 0.08 & 0.48 & 0.11 \\
\hline $\mathrm{CP}$ concentration ${ }^{5} \mathrm{~g} / \mathrm{kg}$ & 35.2 & 38.5 & 37.6 & 41.6 & 0.87 & $<0.01$ & $<0.01$ & 0.58 \\
\hline
\end{tabular}

\footnotetext{
${ }^{1}$ Average of the last 6 milkings.

${ }^{2} \mathrm{Ctrl}=$ water infusion; $\mathrm{AA}_{\mathrm{CN}}=695 \mathrm{~g} / \mathrm{d} \mathrm{AA}$ mixture with casein profile infusion; $\mathrm{E}_{\mathrm{Glc}}=1,454 \mathrm{~g} / \mathrm{d}$ glucose infusion; $\mathrm{AA}_{\mathrm{CN}}+\mathrm{E}_{\mathrm{Glc}}=$ combination of AA mixture and glucose infusion.

${ }^{3} \mathrm{SEM}$ given for $\mathrm{n}=4$.

${ }^{4}$ Probability values correspond to the effect of AA (without vs. with AA infusion), Glc (without vs. with glucose infusion), and AA $\times$ Glc interaction.

${ }^{5} \mathrm{CP}=$ total N milk $\times 6.34$, as proposed by Karman and van Boekel (1986).
} 
Table 6. Effects of AA and glucose infusions on the efficiency ${ }^{1}$ of use of individual EAA, MP, and groups of AA

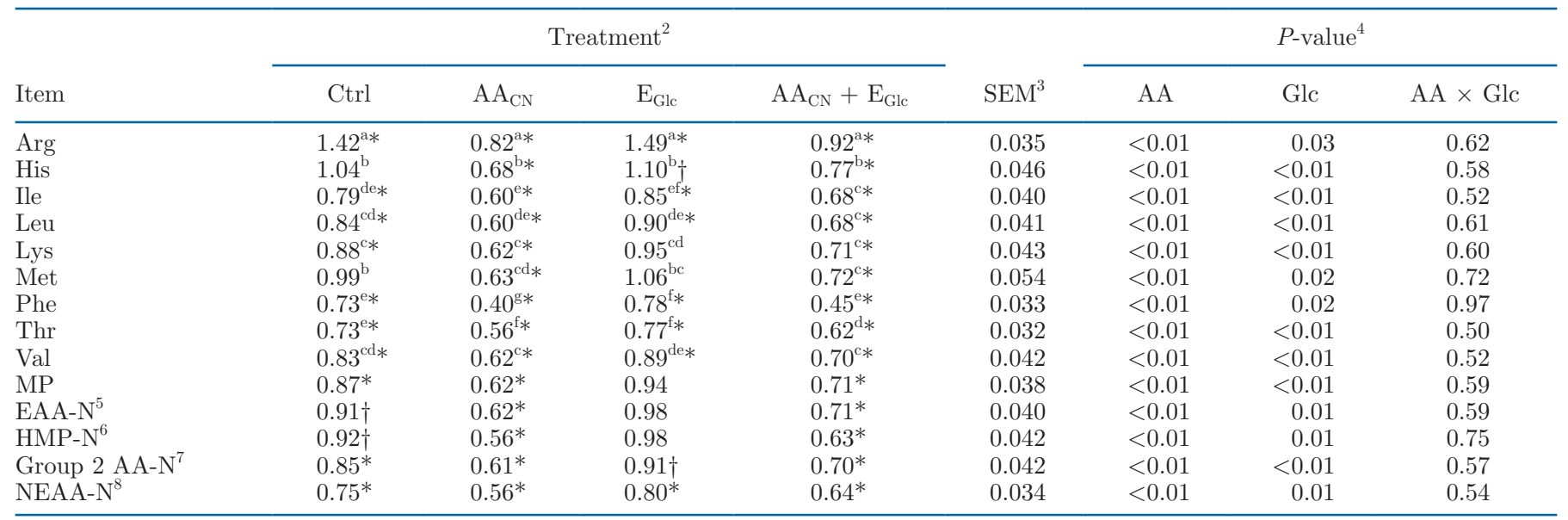

${ }^{\mathrm{a}-\mathrm{g}}$ Within a column, values with a different superscripts differ; only tested within individual EAA.

${ }^{1}$ Efficiency was calculated as individual AA or groups of AA: (milk protein + metabolic fecal protein + scurf)/(supply - endogenous urinary loss); see the Calculations section for details.

${ }^{2} \mathrm{Ctrl}=$ water infusion; $\mathrm{AA}_{\mathrm{CN}}=695 \mathrm{~g} / \mathrm{d}$ AA mixture with casein profile infusion; $\mathrm{E}_{\mathrm{Glc}}=1,454 \mathrm{~g} / \mathrm{d}$ glucose infusion; $\mathrm{AA}_{\mathrm{CN}}+\mathrm{E}_{\mathrm{Glc}}=$ combination of AA mixture and glucose infusion.

${ }^{3} \mathrm{SEM}$ given for $\mathrm{n}=4$.

${ }^{4}$ Probability values correspond to the effect of AA (without vs. with AA infusion), Glc (without vs. with glucose infusion), and AA $\times$ Glc interaction.

${ }^{5} \mathrm{EAA}-\mathrm{N}=$ sum of Arg, His, Ile, Leu, Lys, Met, Phe, Thr, and Val.

${ }^{6} \mathrm{HMP}-\mathrm{N}=$ sum of His, Met, and Phe, used in Table 12.

${ }^{7}$ Group 2 AA-N = sum of Ile, Leu, Lys, and Val.

${ }^{8} \mathrm{NEAA}-\mathrm{N}=$ obtained by the difference between MP and EAA-N.

*Different from 1 at $P \leq 0.05$.

$\dagger$ Different from 1 at $0.05<P \leq 0.10$.

on an individual basis, glucose infusion decreased $(P$ $\leq 0.05)$ Arg, Ile, Leu, Lys, Phe, Val, and Orn arterial concentrations; tended $(P \leq 0.10)$ to decrease Ala and Cys arterial concentrations; but increased $(P \leq 0.03)$ arterial concentrations of Gly and Ser. Glucose infusion decreased $(P \leq 0.04)$ the arterial concentrations of TAA-N, EAA-N, group 2 AA-N, and BCAA-N. The arterial concentration of urea increased with AA infusion $(+126 \% ; P<0.01)$ and decreased with glucose infusion $(-24 \% ; P<0.01)$.

\section{Net Fluxes of Individual AA and Urea Across Tissues}

Splanchnic Fluxes. Portal and hepatic plasma flows were not altered by AA infusion but tended ( $P$ $=0.06$; Table 8 ) to increase with glucose infusion. The net fluxes of individual AA are detailed in Table 9 . The portal net fluxes of all individual AA increased $(P \leq 0.05)$ with AA infusion with the exception of a tendency $(P=0.06)$ for Asn and no effect for Asp, Cit, and Tyr. The portal net fluxes of AA were not affected by glucose infusion, except for Gln, which decreased ( $P$ $<0.01)$. The portal net flux of Cit had a tendency for an AA $\times$ Glc interaction $(P=0.08)$, but differences did not reach significance $(P>0.10)$ when tested within type of infusions. The portal net flux of urea decreased $(P<0.01)$ with AA infusion and was not affected by glucose infusion.

Infusions of AA increased $(P \leq 0.03)$ hepatic removals of Arg, His, Lys, Met, Phe, and Thr and of Ala, Cys, Gln, Gly, Pro, and Ser and tended $(P=0.08)$ to increase hepatic removal of Asn. Among individual EAA, hepatic removals of His, Met, Phe, and Thr decreased $(P \leq 0.04)$ and those of Arg and Lys tended $(P \leq 0.08)$ to decrease with glucose infusion. The hepatic removal of Ala decreased $(P<0.01)$ with glucose infusion. Hepatic release of Glu decreased $(P=0.02)$ with AA infusion but increased $(P<0.01)$ with glucose infusion. Net hepatic release of urea increased with AA infusion $(P<0.01)$ and decreased with glucose infusion $(P=0.01)$.

Among individual EAA, only the splanchnic net flux of AA from group 2 AA increased $(P \leq 0.03)$, whereas those of Met and Thr tended $(P \leq 0.10)$ to increase with AA infusion. The splanchnic net flux of Pro was the only NEAA to increase $(P<0.01)$ with AA infusion, but the splanchnic net flux of Asn also tended $(P=$ $0.06)$ to increase, whereas splanchnic net flux decreased 
Table 7. Effects of AA and glucose infusions on plasma arterial concentrations $(\mu M)$

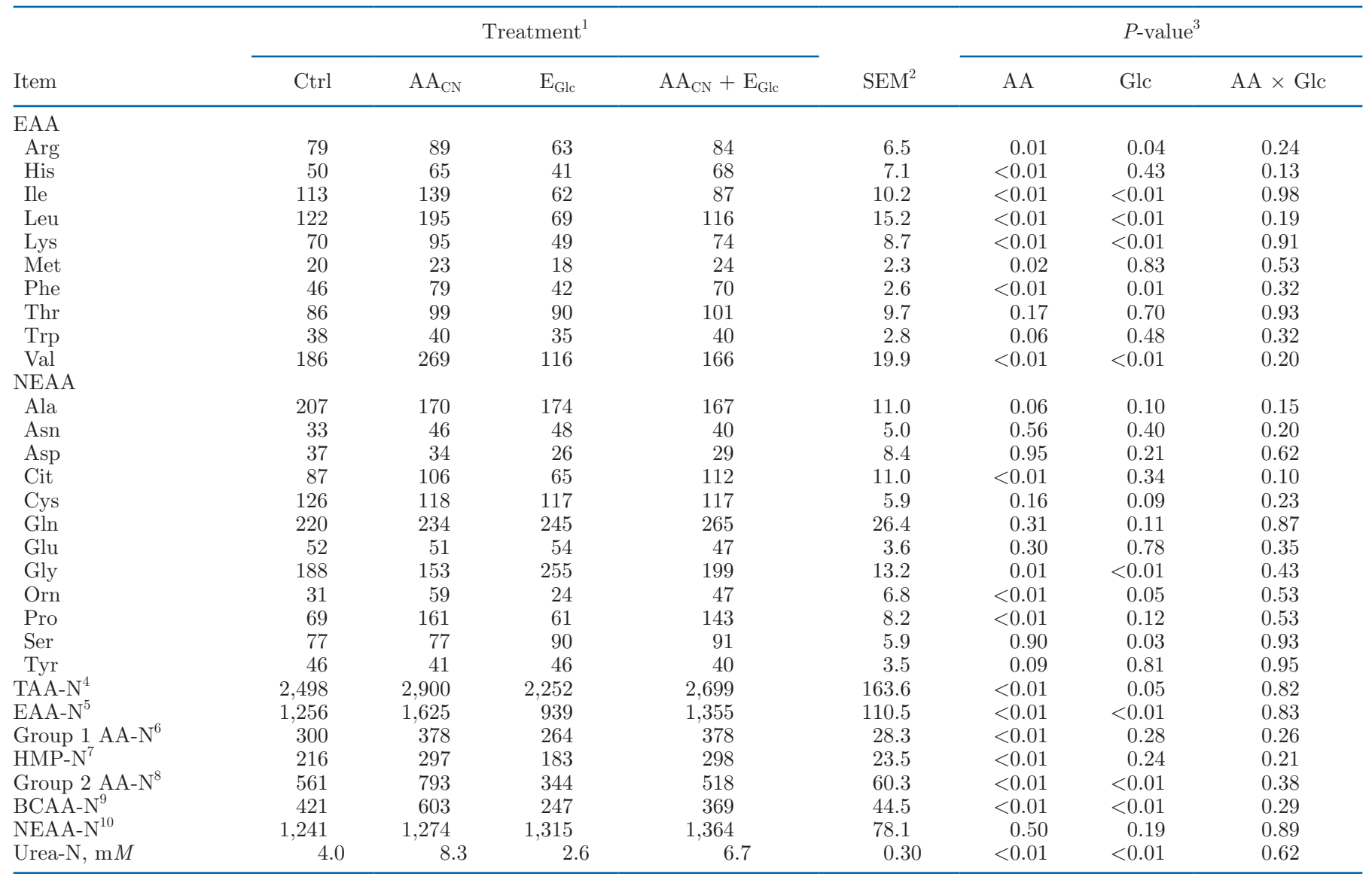

${ }^{1} \mathrm{Ctrl}=$ water infusion; $\mathrm{AA}_{\mathrm{CN}}=695 \mathrm{~g} / \mathrm{d} \mathrm{AA}$ mixture with casein profile infusion; $\mathrm{E}_{\mathrm{Glc}}=1,454 \mathrm{~g} / \mathrm{d}$ glucose infusion; $\mathrm{AA}_{\mathrm{CN}}+\mathrm{E}_{\mathrm{Glc}}=$ combination of AA mixture and glucose infusion.

${ }^{2}$ SEM given for $\mathrm{n}=4$.

${ }^{3}$ Probability values correspond to the effect of AA (without vs. with AA infusion), Glc (without vs. with glucose infusion), and AA $\times$ Glc interaction.

${ }^{4}$ TAA-N = sum of Ala, Arg, Asp, Cys, Gln, Glu, Gly, His, Ile, Leu, Lys, Met, Phe, Pro, Ser, Thr, Trp, Tyr, and Val.

${ }^{5}$ EAA-N = sum of Arg, His, Ile, Leu, Lys, Met, Phe, Thr, Trp, and Val.

${ }^{6}$ Group 1 AA-N = sum of His, Met, Phe, Trp, and Tyr.

${ }^{7} \mathrm{HMP}-\mathrm{N}=$ sum of His, Met, and Phe, used in Table 12.

${ }^{8}$ Group 2 AA-N = sum of Ile, Leu, Lys, and Val.

${ }^{9}$ BCAA-N $=$ sum of Ile, Leu, and Val.

${ }^{10}$ NEAA-N = sum of Ala, Asp, Cys, Gln, Glu, Gly, Pro, Ser, and Tyr.

Table 8. Effects of AA and glucose infusions on plasma flows $(\mathrm{L} / \mathrm{h})$

\begin{tabular}{|c|c|c|c|c|c|c|c|c|}
\hline \multirow[b]{2}{*}{ Tissue } & \multicolumn{4}{|c|}{ Treatment $^{1}$} & \multirow[b]{2}{*}{$\mathrm{SEM}^{2}$} & \multicolumn{3}{|c|}{$P$-value ${ }^{3}$} \\
\hline & Ctrl & $\mathrm{AA}_{\mathrm{CN}}$ & $\mathrm{E}_{\mathrm{Glc}}$ & $\mathrm{AA}_{\mathrm{CN}}+\mathrm{E}_{\mathrm{Glc}}$ & & AA & Glc & $\mathrm{AA} \times \mathrm{Glc}$ \\
\hline Splanchnic & 1,192 & 1,163 & 1,233 & 1,257 & 97.1 & 0.93 & 0.06 & 0.41 \\
\hline Mammary & 593 & 561 & 669 & 753 & 57.4 & 0.44 & $<0.01$ & 0.10 \\
\hline
\end{tabular}

${ }^{1} \mathrm{Ctrl}=$ water infusion; $\mathrm{AA}_{\mathrm{CN}}=695 \mathrm{~g} / \mathrm{d}$ AA mixture with casein profile infusion; $\mathrm{E}_{\mathrm{Glc}}=1,454 \mathrm{~g} / \mathrm{d}$ glucose infusion; $\mathrm{AA}_{\mathrm{CN}}+\mathrm{E}_{\mathrm{Glc}}=$ combination of AA mixture and glucose infusion.

${ }^{2} \mathrm{SEM}$ given for $\mathrm{n}=4$.

${ }^{3}$ Probability values correspond to the effect of AA (without vs. with AA infusion), Glc (without vs. with glucose infusion), and AA $\times$ Glc interaction. 
Table 9. Effects of AA and glucose infusions on net fluxes of portal-drained viscera (PDV), hepatic tissues (HEP), splanchnic tissues (TSP), and mammary gland $(\mathrm{MG})$ and milk output $\left(\mathrm{Milk}^{1}\right)$ of individual AA and urea-N $(\mathrm{mmol} / \mathrm{h})$

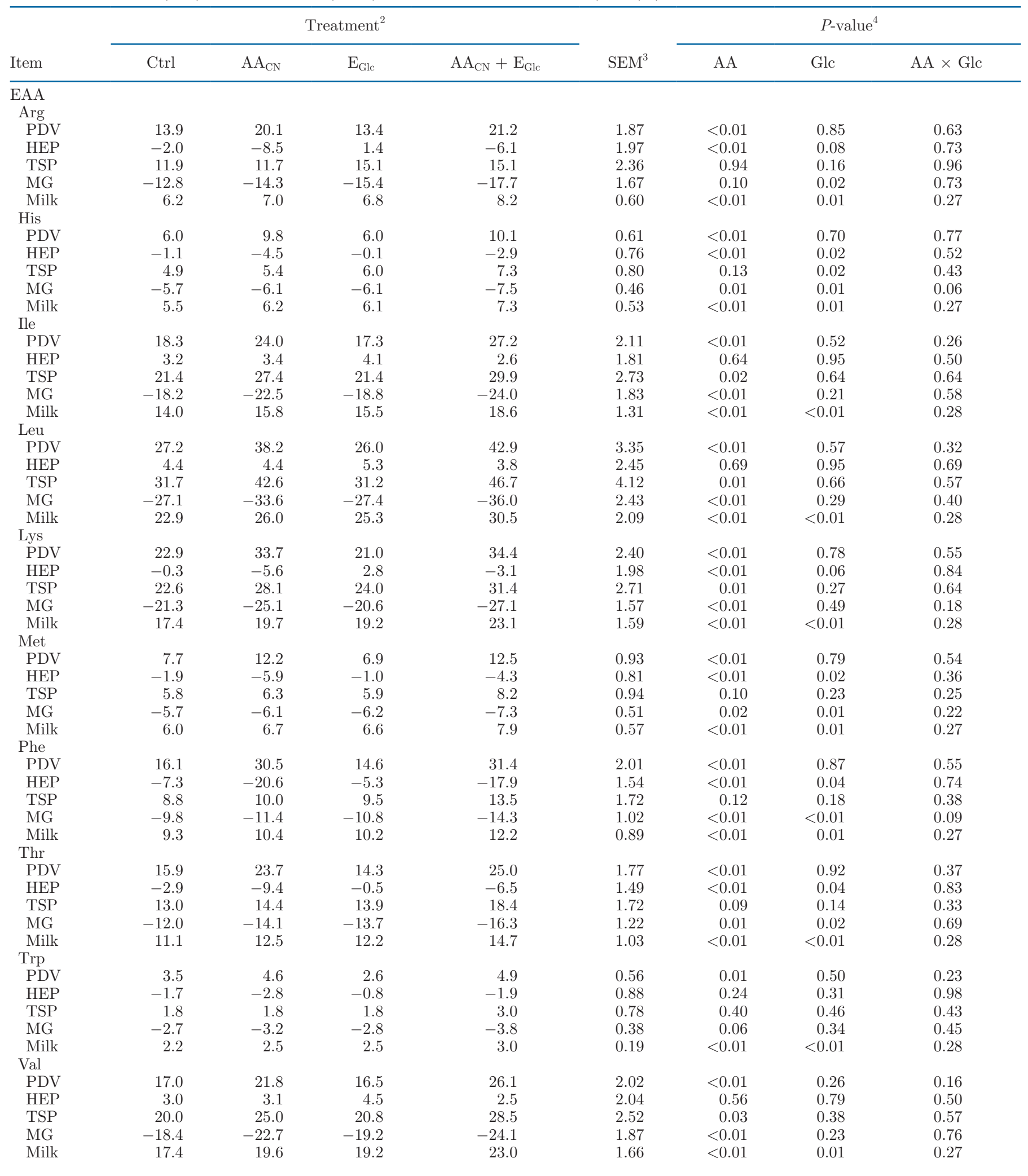


Table 9 (Continued). Effects of AA and glucose infusions on net fluxes of portal-drained viscera (PDV), hepatic tissues (HEP), splanchnic tissues (TSP), and mammary gland (MG) and milk output (Milk $\left.{ }^{1}\right)$ of individual AA and urea-N (mmol/h)

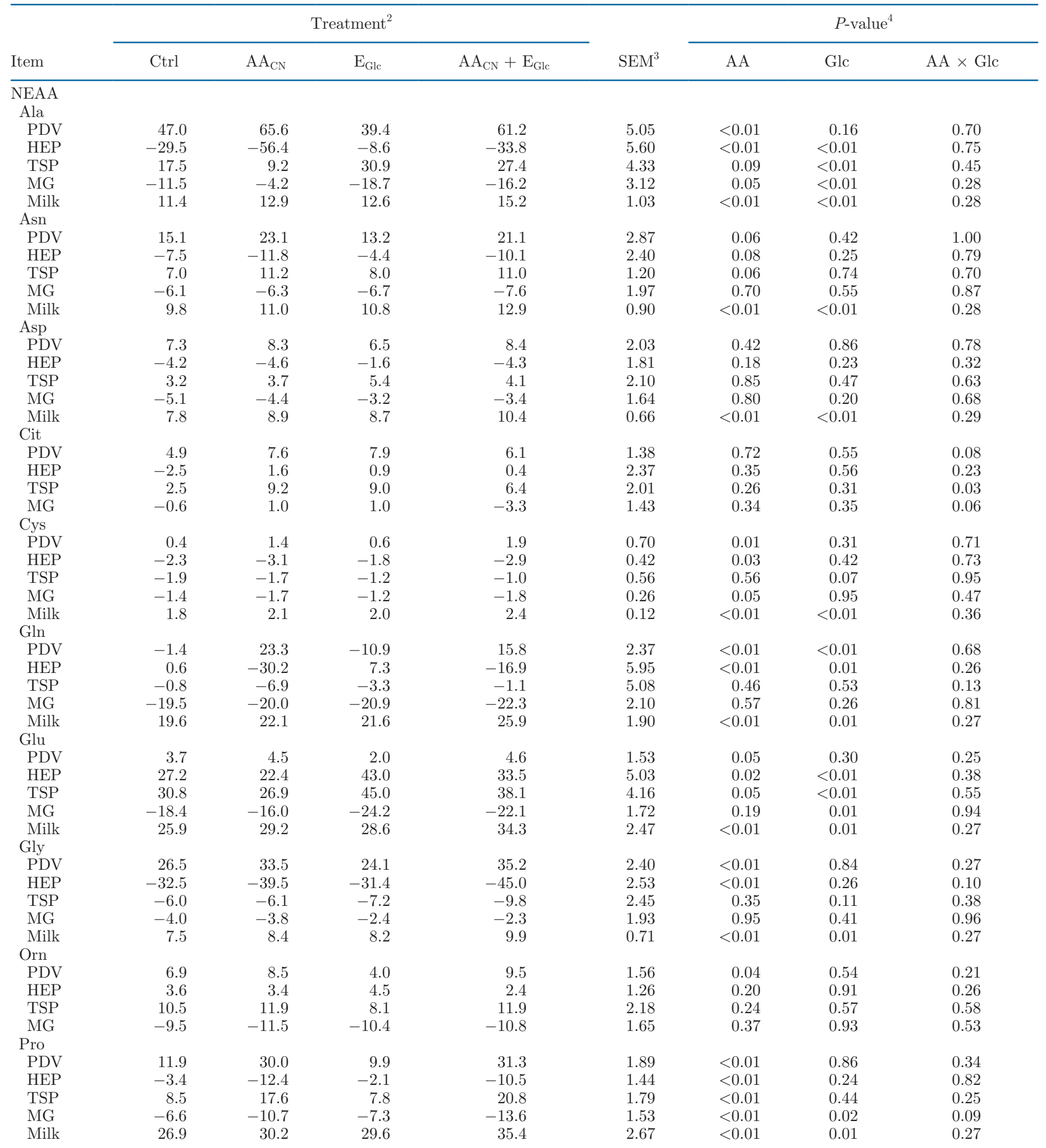


Table 9 (Continued). Effects of AA and glucose infusions on net fluxes of portal-drained viscera (PDV), hepatic tissues (HEP), splanchnic tissues (TSP), and mammary gland (MG) and milk output (Milk $\left.{ }^{1}\right)$ of individual AA and urea-N (mmol/h)

\begin{tabular}{|c|c|c|c|c|c|c|c|c|}
\hline Item & \multicolumn{4}{|c|}{ Treatment $^{2}$} & $\mathrm{SEM}^{3}$ & \multicolumn{3}{|c|}{$P$-value ${ }^{4}$} \\
\hline \multicolumn{9}{|l|}{ Ser } \\
\hline HEP & -20.7 & -33.8 & -21.3 & -33.5 & 2.12 & $<0.01$ & 0.92 & 0.79 \\
\hline TSP & 4.4 & 6.3 & 5.4 & 9.1 & 2.56 & 0.21 & 0.39 & 0.68 \\
\hline MG & -8.7 & -10.5 & -11.6 & -13.9 & 1.90 & 0.19 & 0.06 & 0.86 \\
\hline PDV & 14.0 & 13.7 & 12.8 & 14.7 & 1.04 & 0.35 & 0.91 & 0.19 \\
\hline HEP & -6.0 & -6.1 & -4.7 & -5.6 & 0.98 & 0.44 & 0.19 & 0.56 \\
\hline TSP & 8.0 & 7.5 & 8.1 & 9.1 & 1.12 & 0.77 & 0.39 & 0.44 \\
\hline MG & -9.1 & -9.7 & -10.0 & -10.7 & 0.96 & 0.24 & 0.09 & 1.00 \\
\hline Milk & 9.6 & 10.8 & 10.5 & 12.6 & 0.93 & $<0.01$ & 0.01 & 0.27 \\
\hline \multicolumn{9}{|l|}{ Urea-N } \\
\hline PDV & -309 & -497 & -241 & -440 & 71.0 & $<0.01$ & 0.29 & 0.92 \\
\hline
\end{tabular}

${ }^{1}$ The milk output associated with mammary uptake excluded blood-borne proteins, as detailed in the Calculations section.

${ }^{2} \mathrm{Ctrl}=$ water infusion; $\mathrm{AA}_{\mathrm{CN}}=695 \mathrm{~g} / \mathrm{d}$ AA mixture with casein profile infusion; $\mathrm{E}_{\mathrm{Glc}}=1,454 \mathrm{~g} / \mathrm{d}$ glucose infusion; $\mathrm{AA}_{\mathrm{CN}}+\mathrm{E}_{\mathrm{Glc}}=$ combination of AA mixture and glucose infusion.

${ }^{3} \mathrm{SEM}$ given for $\mathrm{n}=4$.

${ }^{4}$ Probability values correspond to the effect of AA (without vs. with AA infusion), Glc (without vs. with glucose infusion), and AA $\times$ Glc interaction.

$(P=0.05)$ for Glu or tended $(P=0.09)$ to decrease for Ala. The splanchnic net flux of His increased $(P=0.02)$ with glucose infusion. For individual NEAA, splanchnic net fluxes of Ala and Glu increased $(P \leq 0.01)$ with glucose infusion. The net splanchnic removal of Cys tended to decrease $(P=0.07)$ with glucose infusion. An AA $\times$ Glc interaction was significant for splanchnic net flux of Cit $(P=0.03)$; AA infusion increased it only without glucose infusion $(P<0.01)$ and glucose infusion increased it only without AA infusion $(P=$ 0.03). The splanchnic net flux of urea increased with AA infusion $(P<0.01)$ and was not affected by glucose infusion.

Fractional removals of individual EAA removed by the liver, except Trp, increased $(P \leq 0.01)$ with AA infusion, whereas fractional removals of His, Phe, and Thr decreased $(P \leq 0.05)$ or tended to decrease $(P \leq$ 0.07 ) for Arg, Lys, and Met with glucose infusion (Table 10). For the NEAA, fractional removals increased $(P \leq$ 0.05) with AA infusion for Ala, Asp, Cys, Gln, Gly, Pro, and Ser. Fractional hepatic removals of His, Phe, Thr, Ala, Gln, and Gly decreased $(P \leq 0.03)$ or tended to decrease $(P \leq 0.03)$ for Arg, Lys, and Met with glucose infusion.

Mammary Uptake of Individual $A A$ and $A A$ in Milk. Mammary plasma flow did not change with AA infusion but increased $(P<0.01$; Table 8$)$ with glucose infusion. The net mammary uptakes of all individual EAA increased $(P \leq 0.02$; Table 9$)$ with AA infusion, except for a tendency to increase for Arg and Trp $(P$ $\leq 0.10)$. However, we observed a tendency for an AA $\times$ Glc interaction $(P=0.06)$ in His mammary uptake; the increment was significant only when glucose was infused $(P<0.01)$. Among NEAA, mammary uptake of Cys increased $(P \leq 0.05)$ with AA infusion, whereas mammary uptake of Ala decreased $(P=0.05)$. Glucose infusion increased $(P \leq 0.02)$ mammary uptakes of Arg, Met, Phe, and Thr. As previously mentioned, a tendency for an AA $\times$ Glc interaction existed $(P=$ $0.06)$ for His mammary uptake; glucose infusion was significant only with AA infusion $(P<0.01)$. Among NEAA, Ala and Glu mammary uptakes increased $(P$ $\leq 0.01)$ with glucose infusion, whereas increased Ser and Tyr mammary uptakes only reached tendency $(P$ $\leq 0.09)$. We observed also a tendency for an AA $\times$ Glc interaction $(P=0.09)$ for Pro mammary uptake. Amino acid infusion increased more Pro mammary uptake with glucose infusion, and glucose infusion was significant only with AA infusion $(P<0.01)$.

Mammary fractional removals of individual AA decreased ( $P \leq 0.05$, Table 10) with AA infusion for His, Leu, Lys, Phe, Ala, Glu, and Pro; tended to decrease $(P=0.06)$ for Val; and increased $(P=0.05)$ for Cys. On the other hand, glucose infusion increased $(P<$ 0.01) fractional removals of Ile, Leu, Val, Ala, and Glu; tended to increase $(P=0.06)$ fractional removal of Lys; but decreased $(P \leq 0.03)$ those of Asp and Gln and tended to decrease $(P=0.09)$ for Cys. 
Similar to MPY, AA or glucose infusion increased all milk protein output (U:O, Table 11) of Ile, Leu, Lys, individual AA exported into milk protein $(P<0.01 ; \quad$ Phe, and Pro increased $(P \leq 0.03)$ with AA infusion, Table 9). The ratios of mammary uptake relative to whereas those of Val tended to increase $(P=0.08)$. In

Table 10. Effects of AA and glucose infusions on fractional removal ${ }^{1}$ of AA by the liver and the mammary gland

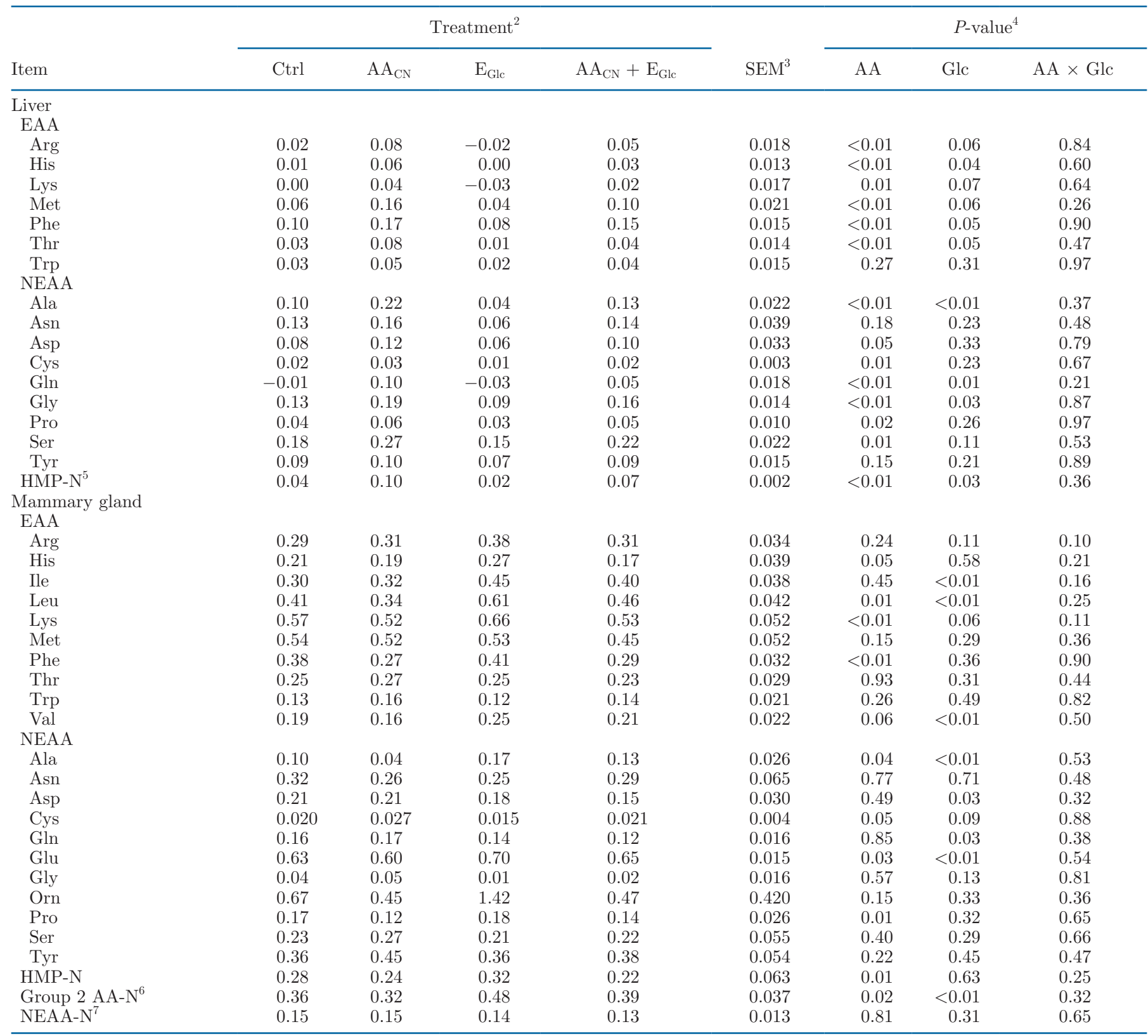

${ }^{1}$ Fractional removal was calculated as - (net flux across the tissue/total influx). Values for AA released by the tissue for all treatments are not reported. A negative value indicates a release for that treatment.

${ }^{2} \mathrm{Ctrl}=$ water infusion; $\mathrm{AA}_{\mathrm{CN}}=695 \mathrm{~g} / \mathrm{d}$ AA mixture with casein profile infusion; $\mathrm{E}_{\mathrm{Glc}}=1,454 \mathrm{~g} / \mathrm{d}$ glucose infusion; $\mathrm{AA}_{\mathrm{CN}}+\mathrm{E}_{\mathrm{Glc}}=$ combination of AA mixture and glucose infusion.

${ }^{3} \mathrm{SEM}$ given for $\mathrm{n}=4$.

${ }^{4}$ Probability values correspond to the effect of AA (without vs. with AA infusion), effect of Glc (without vs. with glucose infusion), and the interaction between $\mathrm{AA}$ and Glc $(\mathrm{AA} \times \mathrm{Glc})$.

${ }^{5} \mathrm{HMP}-\mathrm{N}=$ sum of His, Met, and Phe.

${ }^{6}$ Group 2 AA-N = sum of Ile, Leu, Lys, and Val.

${ }^{7}$ NEAA-N = sum of Ala, Asp, Cys, Gln, Glu, Gly, Pro, Ser, and Tyr. 
Table 11. Effects of AA and glucose infusions on the ratio of mammary uptake to milk output ${ }^{1}$ of AA

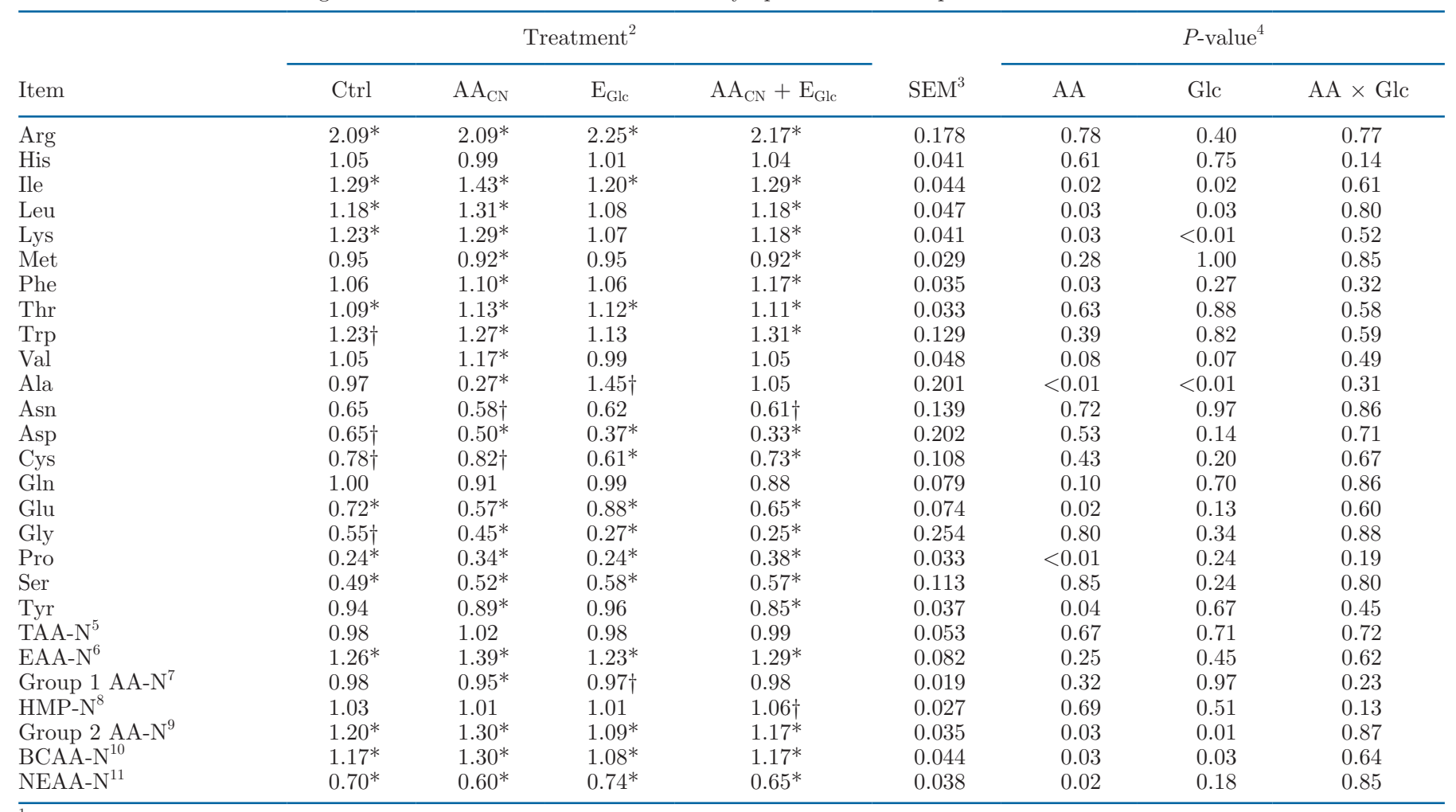

${ }^{1}$ The milk output associated with mammary uptake excludes blood-borne proteins, as detailed in the Calculations section.

${ }^{2} \mathrm{Ctrl}=$ water infusion; $\mathrm{AA}_{\mathrm{CN}}=695 \mathrm{~g} / \mathrm{d} \mathrm{AA}$ mixture with casein profile infusion; $\mathrm{E}_{\mathrm{Glc}}=1,454 \mathrm{~g} / \mathrm{d}$ glucose infusion; $\mathrm{AA}_{\mathrm{CN}}+\mathrm{E}_{\mathrm{Glc}}=$ combination of AA mixture and glucose infusion.

${ }^{3} \mathrm{SEM}$ given for $\mathrm{n}=4$.

${ }^{4}$ Probability values correspond to the effect of AA (without vs. with AA infusion), Glc (without vs. with glucose infusion), and AA $\times$ Glc interaction.

${ }^{5}$ TAA-N = sum of Ala, Arg, Asp, Cys, Gln, Glu, Gly, His, Ile, Leu, Lys, Met, Phe, Pro, Ser, Thr, Trp, Tyr, and Val.

${ }^{6} \mathrm{EAA}-\mathrm{N}=$ sum of Arg, His, Ile, Leu, Lys, Met, Phe, Thr, Trp, and Val.

${ }^{7}$ Group 1 AA-N = sum of His, Met, Phe, Trp, and Tyr.

${ }^{8} \mathrm{HMP}-\mathrm{N}=$ sum of His, Met, and Phe, used in Table 12.

${ }^{9}$ Group 2 AA-N $=$ sum of Ile, Leu, Lys, and Val.

${ }^{10}$ BCAA-N $=$ sum of Ile, Leu, and Val.

${ }^{11}$ NEAA-N = sum of Ala, Asp, Cys, Gln, Glu, Gly, Pro, Ser, and Tyr.

*Different from 1 at $P \leq 0.05$.

$\dagger$ Different from 1 at $0.05<P \leq 0.10$.

contrast, AA infusion decreased $(P \leq 0.04)$ the $\mathrm{U}: \mathrm{O}$ of Ala, Glu, and Tyr and tended to decrease the Gln U:O $(P=0.10)$. With glucose infusion, the $\mathrm{U}: \mathrm{O}$ of Ile, Leu, and Lys decreased $(P \leq 0.03)$, whereas we observed only a tendency to decrease for Val $(P=0.07)$. The $\mathrm{U}: \mathrm{O}$ of Ala increased $(P<0.01)$ with glucose infusion.

\section{Metabolic Fates of Groups of AA by Tissue}

The metabolism of EAA will be followed by groups and not as total EAA, because of the large dissimilarity between the pattern of use of group 1 versus group 2 EAA. However, because we wanted to integrate mea- surements of net fluxes with predicted digestible flows, the HMP-N group (i.e., the sum of His, Met, and Phe) was created to replace group $1 \mathrm{AA}-\mathrm{N}$ because the NRC (2001) does not predict Trp and Tyr digestible flows. It is acknowledged that the metabolism of NEAA also differs greatly among NEAA, but because there is no prediction of individual NEAA digestible flows by the NRC (2001), these were estimated as a group by difference between TAA-N and EAA-N and will therefore be considered as a single group.

Net Fluxes of Groups of AA. The net fluxes of groups of AA-N are reported in Table 12. The portal net fluxes of HMP-N, group 2 AA-N, and NEAA-N 
Table 12. Effects of AA and glucose infusions on supply, net flux (NF), and use of groups of AA by portal-drained viscera (PDV), hepatic tissues (HEP), splanchnic tissues (TSP), and mammary gland (MG) and resulting estimated catabolism ( $\mathrm{mmol}$ of $\mathrm{N} / \mathrm{h}$ )

\begin{tabular}{|c|c|c|c|c|c|c|c|c|}
\hline \multirow[b]{2}{*}{ Item $^{1}$} & \multicolumn{4}{|c|}{ Treatment $^{2}$} & \multirow[b]{2}{*}{$\mathrm{SEM}^{3}$} & \multicolumn{3}{|c|}{$P$-value ${ }^{4}$} \\
\hline & Ctrl & $\mathrm{AA}_{\mathrm{CN}}$ & $\mathrm{E}_{\mathrm{Glc}}$ & $\mathrm{AA}_{\mathrm{CN}}+\mathrm{E}_{\mathrm{Glc}}$ & & AA & Glc & $\mathrm{AA} \times \mathrm{Glc}$ \\
\hline Supply & 620 & 905 & 621 & 904 & 31.3 & $<0.01$ & 0.75 & 0.31 \\
\hline Endo Uri & 99.7 & 99.7 & 101.3 & 99.7 & - & - & - & - \\
\hline MFP & 107 & 107 & 107 & 107 & 4.9 & 0.28 & 0.82 & 0.47 \\
\hline Scurf & 3.9 & 3.9 & 3.9 & 3.9 & - & - & - & - \\
\hline Supply & 49 & 88 & 49 & 88 & 2.3 & $<0.01$ & 0.55 & 0.32 \\
\hline Endo Uri & 2 & 2 & 2 & 2 & - & - & - & - \\
\hline $\mathrm{MFP}$ & 10 & 10 & 10 & 10 & 0.5 & 0.28 & 0.82 & 0.47 \\
\hline $\mathrm{PDV}_{\text {catabolism }}$ & -3 & 5 & -1 & 3 & 5.0 & 0.18 & 0.99 & 0.60 \\
\hline $\mathrm{PDV}_{\mathrm{NF}}$ & 42 & 72 & 40 & 74 & 4.6 & $<0.01$ & 1.00 & 0.61 \\
\hline $\mathrm{HEP}_{\mathrm{NF}}$ & $-12^{*}$ & $-40^{*}$ & -7 & $-30^{*}$ & 4.2 & $<0.01$ & 0.01 & 0.40 \\
\hline $\mathrm{TSP}_{\mathrm{NF}}$ & 29 & 32 & 33 & 44 & 4.7 & 0.08 & 0.05 & 0.28 \\
\hline \multicolumn{9}{|l|}{ Group 2 AA-N } \\
\hline Supply & 144 & 219 & 144 & 218 & 6.6 & $<0.01$ & 0.40 & 0.08 \\
\hline Endo Uri & 4.0 & 4.0 & 4.0 & 4.0 & - & - & - & - \\
\hline MFP & 26 & 26 & 26 & 26 & 1.2 & 0.28 & 0.82 & 0.47 \\
\hline $\mathrm{PDV}_{\text {catabolism }}$ & 11 & $41^{*}$ & 17 & $27^{*}$ & 12.6 & 0.07 & 0.71 & 0.35 \\
\hline $\mathrm{PDV}_{\mathrm{NF}}$ & 108 & 152 & 102 & 165 & 11.6 & $<0.01$ & 0.73 & 0.36 \\
\hline $\mathrm{HEP}_{\mathrm{NF}}$ & 10 & 0 & $19 \dagger$ & 3 & 9.0 & 0.06 & 0.33 & 0.59 \\
\hline $\mathrm{TSP}_{\mathrm{NF}}$ & 117 & 152 & 122 & 168 & 14.2 & 0.01 & 0.43 & 0.64 \\
\hline Scurf & 0.7 & 0.7 & 0.7 & 0.7 & - & - & - & - \\
\hline Peri $_{\text {catabolism }}$ & 10 & $22 *$ & 14 & $29 *$ & 12.9 & 0.21 & 0.61 & 0.91 \\
\hline $\mathrm{MG}_{\mathrm{NF}}$ & -107 & -129 & -108 & -138 & 9.1 & $<0.01$ & 0.28 & 0.33 \\
\hline $\mathrm{MG}_{\text {catabolism }}$ & $15^{*}$ & $25^{*}$ & $6^{*}$ & $16^{*}$ & 2.8 & $<0.01$ & 0.01 & 0.89 \\
\hline Milk & 92 & 104 & 101 & 122 & 8.5 & $<0.01$ & $<0.01$ & 0.27 \\
\hline $\mathrm{MG}_{\mathrm{NF}}$ & -108 & -104 & -124 & -137 & 10.2 & 0.49 & $<0.01$ & 0.22 \\
\hline $\mathrm{MG}_{\text {cattabolism }}$ & $-63^{*}$ & $-89^{*}$ & $-65^{*}$ & $-90^{*}$ & 12.2 & $<0.01$ & 0.88 & 0.94 \\
\hline Milk $^{5}$ & 172 & 194 & 189 & 227 & 16.2 & $<0.01$ & $<0.01$ & 0.27 \\
\hline
\end{tabular}

${ }^{1}$ Endo Uri $=$ endogenous urinary loss; MFP $=$ metabolic fecal protein; HMP-N $=$ sum of His, Met, and Phe; PDV catabolism $=$ catabolism across PDV; Peri catabolism $_{=}$catabolism across peripheral tissues other than the MG; $\mathrm{MG}_{\text {catabolism }}=$ catabolism across the MG; Group $2 \mathrm{AA}-\mathrm{N}=$ sum of Ile, Leu, Lys, and Val; NEAA-N = sum of Ala, Asp, Cys, Gln, Glu, Gly, Pro, Ser, and Tyr.

${ }^{2} \mathrm{Ctrl}=$ water infusion; $\mathrm{AA}_{\mathrm{CN}}=695 \mathrm{~g} / \mathrm{d}$ AA mixture with casein profile infusion; $\mathrm{E}_{\mathrm{Glc}}=1,454 \mathrm{~g} / \mathrm{d}$ glucose infusion; $\mathrm{AA}_{\mathrm{CN}}+\mathrm{E}_{\mathrm{Glc}}=$ combination of AA mixture and glucose infusion.

${ }^{3} \mathrm{SEM}$ given for $\mathrm{n}=4$.

${ }^{4}$ Probability values correspond to the effect of AA (without vs. with AA infusion), effect of Glc (without vs. with glucose infusion), and the interaction between $\mathrm{AA}$ and Glc $(\mathrm{AA} \times \mathrm{Glc})$.

${ }^{5}$ Obtained as the difference between MP and EAA-N fractions.

${ }^{*}$ Catabolisms different from 0 at $P \leq 0.05$.

$\dagger$ Catabolisms different from 0 at $0.05<P \leq 0.10$.

increased $(P<0.01)$ with AA infusion and did not change with glucose infusion. The splanchnic net flux of group 2 AA-N increased $(P=0.01)$ and those of HMP-
$\mathrm{N}$ tended to increase $(P=0.08)$ with AA infusion. The splanchnic net flux of HMP-N increased $(P=0.05)$ with glucose infusion. Hepatic fractional removal of HMP-N 
increased $(P \leq 0.01$, Table 10$)$ with AA infusion and decreased $(P=0.03)$ with glucose infusion. The mammary uptake of group 2 AA-N increased $(P<0.05$, Table 12) with AA infusion. The mammary uptake of NEAA-N increased $(P<0.05)$ with glucose infusion. An AA $\times$ Glc interaction $(P=0.05)$ for HMP-N mammary uptake was observed; AA and glucose infusions increased more HMP-N mammary uptake with glucose infusion and AA infusion, respectively. Mammary fractional removal of HMP-N and group 2 AA-N decreased $(P \leq 0.02)$ with AA infusion. Glucose infusion had no effect on HMP-N mammary fractional removal but increased $(P<0.01)$ fractional removal of group 2 AA$N$. Fractional removal of NEAA-N was not affected by treatments (Table 10). Following MPY pattern, groups of AA in MPY increased $(P<0.05)$ with AA or glucose infusion. Moreover, TAA-N in MPY [329, 372, 364, and $436 \pm 31(\mathrm{SEM}) \mathrm{mmol}$ of $\mathrm{N} / \mathrm{h}$ in Ctrl, $\mathrm{AA}_{\mathrm{CN}}, \mathrm{E}_{\mathrm{Glc}}$, and $\mathrm{AA}_{\mathrm{CN}}+\mathrm{E}_{\mathrm{Glc}}$ treatments, respectively] was close to MPY. Overall, the TAA-N U:O was not different from unity $(P>0.10$; Table 11$)$. There was no effect of AA and glucose infusions on the $\mathrm{U}: \mathrm{O}$ of group 1 AA-N. The group 2 AA-N and BCAA-N U:O increased $(P=$ $0.03)$ with AA infusion, whereas these ratios decreased $(P \leq 0.03)$ with glucose infusion. With AA infusion, the NEAA-N U:O decreased $(P=0.02)$ and those of TAA-N tended to decrease $(P=0.09)$, whereas these ratios were not affected by glucose infusion.

Sites of Catabolism of Groups of AA. Catabolism of HMP-N was only different from zero across the liver in Ctrl, $\mathrm{AA}_{\mathrm{CN}}$, and $\mathrm{AA}_{\mathrm{CN}}+\mathrm{E}_{\mathrm{Glc}}$ treatments and was not different from zero across the PDV, the other peripheral tissues, and the mammary gland. In contrast, no significant hepatic removal of group 2 AA-N existed, whereas catabolisms by the PDV and other peripheral tissues were different from zero with AA infusion and mammary catabolism was higher than zero for all treatments. Finally, for NEAA-N, catabolism across the PDV was higher than zero for the 4 treatments. A negative catabolism of the NEAA-N across the mammary gland for all 4 treatments and by other peripheral tissues, only significant $(P \leq 0.10)$ in the Ctrl treatment, indicates de novo synthesis of the NEAA by these tissues. Hepatic removal of NEAA-N existed in all treatments, but it was not significant when glucose was infused.

The catabolism by the PDV of group 2 AA-N tended $(P=0.07)$ to increase with AA infusion. The hepatic removal of HMP-N and NEAA-N increased with AA infusion, suggesting an increased catabolism, and decreased $(P \leq 0.01)$ with glucose infusion, suggesting a decreased catabolism. The tendency $(P=0.06)$ for a decreased hepatic release for group 2 AA-N with AA infusion must be interpreted with caution because it was not significantly different from zero, except a tendency in the $\mathrm{E}_{\mathrm{Glc}}$ treatment. The catabolism by other peripheral tissues was not affected by treatments. The mammary catabolism of group 2 AA-N increased $(P<$ $0.01)$ with AA infusion and decreased $(P=0.01)$ with glucose infusion. The negative mammary catabolism of NEAA-N increased $(P<0.01)$ with AA infusion, indicating increased de novo synthesis of NEAA-N.

\section{DISCUSSION}

\section{Nutrient Supplies}

The DMI were similar between treatments; consequently, AA and glucose infusions created substantial variations in $\mathrm{MP}(+43 \%)$ and $\mathrm{NE}_{\mathrm{L}}(+14 \%)$ supplies, respectively, with no $\mathrm{AA} \times \mathrm{Glc}$ interaction. The increased digestible flow of individual EAA with AA infusion did not rely on the ration formulation model because it is directly related to the infusion. However, the relative increments of the digestible flow of individual EAA varied greatly between EAA due to the difference of AA composition between CN and dietary MP. For example, Thr digestible flow increased by $41 \%$, whereas Met digestible flow increased by $72 \%$; Phe digestible flow had the largest increment $(102 \%)$ due to fact that Phe replaced Tyr in the infusate.

\section{Milk Yield and Composition}

Infusing AA or glucose increased milk yield by 6 and $5 \%$, respectively, although the latter only reached the tendency level. No AA $\times$ Glc interaction existed, indicating that the effects were additive (i.e., they act independently of each other). Also, similarly to milk yield, infusing AA or glucose increased MPY, with no AA $\times$ Glc interaction, the effects being also additive, as previously reported when the effects of protein and energy supplies have been tested in a factorial arrangement (e.g., Clark et al., 1977; Vanhatalo et al., 2003; Raggio et al., 2006a). In a recent meta-analysis, Daniel et al. (2016) also concluded that MP and energy supplies do not interact. Interaction between energy and protein supplies was, however, reported by Brun-Lafleur et al. (2010) using a specific experimental design with many levels of energy and protein supplies. This discrepancy indicates the need to conduct studies thoroughly designed to test the energy $\times$ protein interaction on milk yield and MPY.

The MPY response to AA infusion $(+17 \%)$ was similar to what was usually reported, with a marginal recovery of infused AA into MPY averaging 0.23 , similar 
to marginal protein efficiency reported by Hanigan et al. (1998) and Martineau et al. (2017) of 0.21 and 0.26, respectively, in response to postruminal casein infusions. In contrast, the MPY response to glucose infusion $(+14 \%)$ was slightly larger than the response usually reported with increased energy supply. For example, Curtis et al. (2018), who also infused glucose, reported a $8 \%$ increment, whereas many studies reported just a tendency for increased MPY with infusions of glucose or other energy sources (Rulquin et al., 2004; Raggio et al., 2006a) or no effect of energy infusion (Rius et al., 2010a; Curtis et al., 2014; Nichols et al., 2016). These different effects of energy infusions could be due to the supplementary $\mathrm{NE}_{\mathrm{L}}$ provided by infusions. Raggio et al. (2006a) infused 3.73 Mcal of $\mathrm{NE}_{\mathrm{L}}$ per day from propionate, close to our glucose infusion. In contrast, Curtis et al. (2014) and Nichols et al. (2016) infused only 2.5 and $2.8 \mathrm{Mcal} / \mathrm{d}$, respectively. Moreover, $\mathrm{NE}_{\mathrm{L}}$ supplies of their control treatments were greater than ours [32.1 and $28.4 \mathrm{Mcal} / \mathrm{d}$, respectively, for Curtis et al. (2014) and Nichols et al. (2016) vs. 27.4 Mcal/d in our study]. These differences could explain our marked MPY response to glucose infusion.

\section{Efficiency of Use of MP and EAA}

The decreased efficiency of MP with AA infusion $(-27 \%)$ was the consequence of an increase of MPY smaller than the increase of MP supply, consistent with previous observations (Doepel et al., 2004; Metcalf et al., 2008). In contrast, efficiency of MP increased with glucose infusion by $10 \%$; this increase with glucose infusion was due to an increased MPY with no change in MP supply. In the current context where MP supply was largely increased with AA infusion, the magnitude of the variation of efficiency of MP was less important with increased energy supply than with decreased protein supply as already observed by Omphalius et al. (2019). Moreover, there was no AA $\times$ Glc interaction on efficiency of MP, as previously reported for efficiency of use of N (Broderick, 2003; Rius et al., 2010b).

The highest efficiency of EAA occurred in the $\mathrm{E}_{\mathrm{Glc}}$ treatment, suggesting very limited catabolism of EAA, whereas the lowest efficiencies observed in the $\mathrm{AA}_{\mathrm{CN}}$ treatment suggested increased catabolism. Efficiencies of individual EAA varied following a pattern similar to efficiency of MP but with different ranges of variation. For example, with AA infusion, Phe had the largest variations of efficiency, whereas $\mathrm{Thr}$ showed the smallest variations. These different variations of efficiency of EAA were linked to the relative variations of EAA supplies, due to casein profile infused relative to AA supplied from the diet. Efficiencies of some EAA were not different or even higher than one; this was the case for Arg, His, Lys, and Met under Ctrl and $\mathrm{E}_{\mathrm{GLC}}$ treatments. An efficiency greater than one may be explained by an overestimation of EUL or MFP, an underestimation of the digestible flows of these AA, or an unaccounted source of endogenous supply. The last assumption would involve different metabolic pathways for the $3 \mathrm{AA}$ with the greatest efficiency. For Arg, it is acknowledged that there is significant de novo synthesis in dairy cows, which could account for up to $30 \%$ of the digestible flow (Doepel et al., 2004). For His, a possible endogenous source could be from depletion of muscular intracellular pools of the dipeptides carnosine and anserine or of blood hemoglobin rich in His. For Lys, protein mobilization would need to be assumed, and this route would also provide endogenous supply of all AA. Although we do not have measurements to assess whether protein mobilization occurred when those high efficiencies were observed, splanchnic fluxes greater than mammary uptake would suggest that protein mobilization did not occur in our study. Similarly, Lee et al. (2015) also reported that, with a low protein diet $(13.7 \% \mathrm{CP})$, His and Met had the highest efficiency of use, although their calculation was only varying the efficiency of lactation as the efficiency for maintenance was assumed to be fixed. They also reported a decreased efficiency of Lys and Met when their respective supply was increased. Altogether, these observations suggest that His, Met, and Lys were potentially in short supply, especially under Ctrl and $\mathrm{E}_{\mathrm{GLC}}$ treatments.

In line with previous findings on the effect of AA supply (Hanigan et al., 2004; Raggio et al., 2006b; Nichols et al., 2016), the pattern of plasma urea concentrations was the inverse of estimated efficiencies of MP and EAA-N. A large increase of urea concentration with AA infusion would indicate increased AA catabolism, whereas in contrast, the decreased plasma urea concentrations with glucose infusion, as already observed (Raggio et al., 2006b), is consistent with increased estimated efficiencies, suggesting a reduction of AA catabolism. However, a decreased urea concentration was not observed in Nichols et al. (2016), but the rate of glucose infusion was smaller than in our experiment $(1.0 \mathrm{~kg} / \mathrm{d}$ vs. $1.5 \mathrm{~kg} / \mathrm{d}$ in our study).

Variations of efficiency of MP and efficiency of EAA$\mathrm{N}$ are indicators of whole-body efficiency of use of AA. We wanted to understand better the mechanisms underlying their variations by studying the coordination of use of AA by splanchnic tissues, other peripheral tissues, and the mammary gland, for anabolic or catabolic purposes in response to variations in protein and energy supplies. 


\section{Splanchnic and Mammary Net Fluxes Varied Among EAA}

The portal net fluxes of all EAA infused increased with AA infusion, as usually observed with a postrumen infusion of a mixture of free AA in cows (Larsen et al., 2015) or of casein in sheep (El-Kadi et al., 2006). The apparent recovery of the infused AA reaching portal circulation averaged 109, 78, 69, 66, 77, 89, 83, 86, 100, and $50 \%$ for the EAA Arg, His, Ile, Leu, Lys, Met, Phe, Thr, Trp, and Val, respectively, and 203, 99, 22, 133, 99, 12, 129, 75, and 98\% for the NEAA Ala, Asn, Asp, Cys, Gln, Glu, Gly, Pro, and Ser, respectively. Among the EAA, the BCAA showed the lowest recovery rate, as also observed in cows in early lactation (Larsen et al., 2015). Also, in sheep, among the EAA, only the BCAA had a slope of portal recovery relative to infusion rate of AA (casein) lower than unity (El-Kadi et al., 2006). Low portal recoveries of BCAA suggest that these AA are catabolized by the PDV when supply is increased. Indeed, direct measurements have shown oxidation of Leu across the PDV in lactating dairy cows (Lapierre et al., 2002) and in sheep (Lobley and Lapierre, 2003). Although no statistical effect could be detected, we noted an increase in PDV recovery with glucose infusion $\left(\mathrm{E}_{\mathrm{Glc}}\right.$ and $\mathrm{AA}_{\mathrm{CN}}+\mathrm{E}_{\mathrm{Glc}}$ vs. Ctrl and $\left.\mathrm{AA}_{\mathrm{CN}}\right)$ by 43,32 , and $58 \%$ for Ile, Leu, and Val, suggesting that increased glucose supply might have decreased PDV metabolism of BCAA. Across the NEAA, as also reported in cows (Larsen et al., 2015) and in sheep (El-Kadi et al., 2006), Ala portal net flux increment, greater than infusion rate, suggests increased transamination of pyruvate with increased AA supply. Moreover, Asp and Glu low recovery rates indicate intensive catabolism of these 2 AA by the PDV, in agreement with their large catabolism by the PDV observed in sheep and nonruminant species (Wolff and Bergman, 1972; Windmueller and Spaeth, 1974; Ball, 2002).

The net hepatic removals of His, Lys, Met, Phe, and Thr increased with AA infusion as usually observed with increased protein or AA supply in lactating dairy cows (Raggio et al., 2004; Cantalapiedra-Hijar et al., 2014a; Larsen et al., 2015). It was initially proposed that net hepatic removal of EAA would be driven by the portal net flux (Reynolds, 2006). Indeed, usually, increased portal net flux of EAA leads to increased circulating plasma concentrations. However, a situation where increased net PDV absorption was accompanied by decreased AA concentrations (e.g., when comparing cows before and after calving; Doepel et al., 2009) clearly demonstrated that net hepatic removal was not related to portal net flux. Another proposed option was that total hepatic AA influx would drive the hepatic removal (Hanigan, 2005; Lapierre et al., 2005). How- ever, the effect of both AA and glucose infusions on hepatic fractional removal for HMP-N indicates that no linear relationship existed between net hepatic removal and hepatic influx; therefore, other factors than mass action must have an effect on hepatic AA removal. As previously reported in dairy cows (Raggio et al., 2004; Cantalapiedra-Hijar et al., 2014a), hepatic removals of BCAA were not different from zero, but this observation is not yet explained.

Overall, the TAA-N mammary uptake-to-milk output ratio did not differ from one, but the mammary gland response to AA or glucose infusion differed among groups of AA. On the one hand, the mammary uptake of most EAA increased with AA infusion through increased mammary VA differences (data not shown) with no change in mammary plasma flow as observed previously with increased AA supply [Raggio et al. (2006a) with casein infusion; Nichols et al. (2016) with EAA infusion; Omphalius et al. (2019) with dietary changes], although mammary plasma flow was reported to decrease with increased MP supply (review: Lapierre et al., 2012). For His, Met, and Trp, the increment was just sufficient to cover the increased MPY, as shown by no effect of AA infusion on the U:O. In contrast, the U:O of group 2 AA-N increased with AA infusion, indicating that the mammary uptake increased at a greater rate than the increased MPY response to AA infusion. On the other hand, the mammary uptake responses to glucose infusion occurred differently between EAA. First, for most of the group 1 AA (especially His, Met, and Phe) and Tyr, mammary uptake increased with glucose infusion with unchanged VA differences coupled to an increased mammary plasma flow. Second, glucose infusion did not affect mammary uptake of group 2 AA-N resultant of the 2 components of uptake calculations varying in opposite directions; the VA difference decreased (data not shown), whereas mammary plasma flow increased. In fact, to accompany an increased MPY, an increased mammary uptake of group $1 \mathrm{AA}-\mathrm{N}$ is obligatory if there is a stoichiometric transfer of their uptake to MPY; however, for group 2 AA-N, as their mammary uptake is in excess of MPY, their uptake does not need to increase to support an increment of MPY. This indicates that mammary catabolism of group 2 AA-N is not obligatory, or at least, it can decrease without a negative effect on MPY. Finally, mammary uptake increased with glucose infusion for many NEAA (Ala, Glu, Pro, Ser, and Tyr). The increased Ala and Glu uptakes were already reported by Lemosquet et al. (2010a). Nevertheless, the uptakes were not sufficient to cover the milk output in protein, with Gln being the only NEAA for which the U:O was never lower than one. With AA infusion (i.e., when AA supply was in excess), decreased U:O of Ala, Glu, and 
Tyr indicate increased mammary de novo synthesis. So, overall, although it is acknowledged that AA infusion increases rate of appearance of glucose (Lapierre et al., 2010; Galindo et al., 2011), MPY response to AA infusion was likely not driven by potential increment in glucose availability as MPY increased through different intramammary mechanisms in response to AA or glucose infusion.

Hepatic and mammary fractional removals responded differently to treatments. Infusion of AA infusion increased HMP-N liver fractional removal but decreased their mammary fractional removal, clearly indicating that the liver was coping with increased influx by increasing its removal. At the opposite, infusion of glucose had no effect on mammary fractional removal of HMP$\mathrm{N}$ but decreased their hepatic fractional removal. As mentioned previously, this might suggest that the liver in not only responding to mass action but might also have an active role in decreasing HMP-N catabolism.

\section{Coordination Between Tissues for Use of AA in Response to Changes in AA and Energy Supplies}

As each tissue uses AA for both anabolic and catabolic purposes, it is interesting to analyze the coordinated changes between tissues in response to alteration in MP or energy supplies. Indeed, the efficiency of EAA-N increased with glucose infusion and decreased with AA infusion, but the tissue where the inefficiency occurred varied between AA (i.e., different sites of catabolism could be identified). First, catabolism by the PDV of HMP-N did not differ from zero for the 4 treatments, whereas for group 2 AA-N, we noted a significant PDV catabolism for all treatments. This latter catabolism, linked to low net PDV recoveries, represented between one-third and half of whole-body catabolism, as already observed for Leu in dairy cows (Lapierre et al., 2002). The PDV catabolism tended to increase with AA infusion, similarly to increased Leu oxidation by the PDV with increased MP supply (Lapierre et al., 2002). Second, the hepatic removal of HMP-N decreased with glucose infusion and increased with AA infusion linked to increased and decreased efficiency of HMP-N with glucose and AA infusions, respectively. Liver is the major site of catabolism for HMP group and represented from 85 to $95 \%$ of whole-body catabolism but plays a very minor role in catabolism of group 2 AA. Third, the fact that mammary catabolism of HMP-N was not different from zero agrees with the U:O equal to unity reported in previous studies, which did not change with variations of energy or protein supplies (Clark et al., 1977; Raggio et al., 2006a; Omphalius et al., 2019). This indicates no mammary catabolism as, on a net basis, net HMP-N uptake was transferred to MPY. Consequently, for HMP-N, the variations of efficiency of use were the result of coordinated and opposite actions of the mammary gland and the liver. For example, in response to glucose infusion, increased efficiency of HMP-N resulted from increased mammary uptake to support MPY and decreased hepatic catabolism. The same pattern of U:O and hepatic removal could be observed on 2 EAA, often limiting in dairy rations, His and Met. In contrast, mammary catabolism of group 2 AA-N was present and decreased with glucose infusion. The observed decreased mammary catabolism of BCAA-N with glucose infusion is consistent with the fact that BCAA could provide 3-carbon intermediates and acetyl-CoA as demonstrated by Raggio et al. (2006a), who directly measured Leu oxidation, or by Bequette et al. (2006), who incubated bovine mammary explants to study AA catabolized through the Krebs cycle for energetic purposes. In the Ctrl treatment, we noted that group 2 AA-N were mainly catabolized in the mammary gland, which had a catabolism different from zero. Nevertheless, with AA infusion, other tissues seemed to be involved in catabolism of group 2 AA-N given observed PDV and peripheral tissue catabolisms different from zero in these treatments. With AA infusion, mammary catabolism increased but its proportion relative to total catabolism decreased from 43 to $25 \%$ in Ctrl versus $\mathrm{AA}_{\mathrm{CN}}$ and $\mathrm{AA}_{\mathrm{CN}}+\mathrm{E}_{\mathrm{Glc}}$ treatments, respectively. Consequently, for this group of AA, mammary catabolism and also PDV catabolism could explain the decreased efficiency of use with AA infusion. The data presented indicate that the positive response of MPY to glucose infusion was accompanied by a decreased hepatic removal of HMP-N in the same range than the increased mammary uptake and MPY, whereas for group 2 AA-N, because no net liver removal existed, the decreased catabolism occurred mainly within the mammary gland. However, our net flux measurements do not allow us to delineate whether these decreased catabolisms of EAA are a response to a stimulation of MPY from extra energy supply or whether the increased MPY is the result of sparing these EAA by different tissues.

\section{CONCLUSIONS}

Studying the fate of AA clearly showed that the response of tissue use of AA differs among tissues and the response to changes in AA or glucose supplies is coordinated and explains variations of efficiency of EAA-N. These variations are explained by different anabolic and catabolic fates among groups of AA according to the nutrient supplies. With AA infusion, efficiency of EAA-N decreased because EAA-N in MPY increased to 
a lesser extent than the increased EAA-N supply. The decreased efficiency of EAA-N was related to increased PDV and mammary catabolisms of group 2 AA-N and increased hepatic removal of group 1 AA-N. In contrast, with glucose infusion, increased efficiency of EAA-N was explained by an increased MPY, supported by a similar increased mammary uptake of HMP-N and a decreased hepatic catabolism. In parallel, mammary catabolism of group 2 AA-N decreased, linked to the increased mammary uptake of NEAA-N, which supported the increment of NEAA-N in MPY. This study clearly delineates the coordinated tissue use of AA, between anabolic or catabolic purpose, in response to variations of AA or glucose supplies. This knowledge could improve the prediction of efficiency of EAA, and this information could be used in feeding systems to improve, for a given diet, the prediction of MPY or to identify which AA are potentially in short supply.

\section{ACKNOWLEDGMENTS}

This experiment was supported by Sherbrooke Research and Development Center of Agriculture and Agri-Food Canada (QC, Canada) and the Dairy Farmers of Canada (Ottawa, ON, Canada). The C. Omphalius CIFRE PhD grant was supported by Adisseo S.A.S. France (Antony, France). The authors express sincere appreciation to P. Dubreuil and M. Babkine (Faculty of Veterinary Medicine, University of Montreal, St-Hyacinthe, QC, Canada) for animal surgeries; D. Bournival, M. Leonard, L. Marier, and J. Renaud (Agriculture and Agri-Food Canada, Sherbrooke, QC, Canada) for their dedicated technical help; the barn staff for animal care during the experiment; and S. Methot for his help in the statistical analyses (Agriculture and Agri-Food Canada, Sherbrooke, QC, Canada). The authors have not stated any conflicts of interest.

\section{REFERENCES}

Armstrong, D., and K. Blaxter. 1961. The utilization of the energy of carbohydrate by ruminants. Page 187 in Proc. 2nd Symp. Energy Metab. Eur. Assoc. Anim. Prod., Wageningen, the Netherlands.

Ball, R. 2002. Definition of amino acid requirements in pigs: Partitioning between gut and muscle. Pages 17-26 in Proc. Amino Acids: Meat, Milk and More!, Québec, Canada. Comité organisateur du Congrès CSAS 2002, Québec, QC, Canada.

Bequette, B. J., N. E. Sunny, S. W. El-Kadi, and S. L. Owens. 2006. Application of stable isotopes and mass isotopomer distribution analysis to the study of intermediary metabolism of nutrients. J. Anim. Sci. 84(Suppl.):E50-E59.

Broderick, G. 2003. Effects of varying dietary protein and energy levels on the production of lactating dairy cows. J. Dairy Sci. 86:13701381. https://doi.org/10.3168/jds.S0022-0302(03)73721-7.

Brun-Lafleur, L., L. Delaby, F. Husson, and P. Faverdin. 2010. Predicting energy $\times$ protein interaction on milk yield and milk composition in dairy cows. J. Dairy Sci. 93:4128-4143. https://doi .org/10.3168/jds.2009-2669.
Calder, A. G., K. E. Garden, S. E. Anderson, and G. E. Lobley. 1999. Quantitation of blood and plasma amino acids using isotope dilution electron impact gas chromatography/mass spectrometry with U-C-13 amino acids as internal standards. Rapid Commun. Mass Spectrom. 13:2080-2083. https://doi.org/10.1002/(SICI)1097 -0231(19991115)13:21<2080::AID-RCM755>3.0.CO;2-O.

Canadian Council on Animal Care. 1993. Guide to the Care and Use of Experimental Animals. Vol. 1. 2nd ed. E. D. Olfert, B. M. Cross, and A. A. McWilliam, ed. Canadian Counc. Anim. Care, Ottawa, ON, Canada.

Cant, J., E. DePeters, and R. Baldwin. 1993. Mammary amino acid utilization in dairy cows fed fat and its relationship to milk protein depression. J. Dairy Sci. 76:762-774. https://doi.org/10.3168/jds .S0022-0302(93)77400-7.

Cantalapiedra-Hijar, G., S. Lemosquet, J. M. Rodriguez-Lopez, F. Messad, and I. Ortigues-Marty. 2014a. Diets rich in starch increase the posthepatic availability of amino acids in dairy cows fed diets at low and normal protein levels. J. Dairy Sci. 97:5151-5166. https: //doi.org/10.3168/jds.2014-8019.

Cantalapiedra-Hijar, G., J. P. Peyraud, S. Lemosquet, E. Molina-Alcaide, H. Boudra, P. Nozière, and I. Ortigues-Marty. 2014b. Dietary carbohydrate composition modifies the milk $\mathrm{N}$ efficiency in late lactation cows fed low crude protein diets. Animal 8:275-285. https://doi.org/10.1017/S1751731113002012.

Clark, J. H., H. R. Spires, R. G. Derrig, and M. R. Bennink. 1977. Milk production, nitrogen utilization and glucose synthesis in lactating cows infused postruminally with sodium caseinate and glucose. J. Nutr. 107:631-644. https://doi.org/10.1093/jn/107.4.631.

Curtis, R., J. Kim, D. Bajramaj, J. Doelman, V. Osborne, and J. Cant. 2014. Decline in mammary translational capacity during intravenous glucose infusion into lactating dairy cows. J. Dairy Sci 97:430-438. https://doi.org/10.3168/jds.2013-7252.

Curtis, R. V., J. J. Kim, J. Doelman, and J. P. Cant. 2018. Maintenance of plasma branched-chain amino acid concentrations during glucose infusion directs essential amino acids to extra-mammary tissues in lactating dairy cows. J. Dairy Sci. 101:4542-4553. https: //doi.org/10.3168/jds.2017-13236.

Daniel, J.-B., N. Friggens, P. Chapoutot, H. Van Laar, and D. Sauvant. 2016. Milk yield and milk composition responses to change in predicted net energy and metabolizable protein: A meta-analysis. Animal 10:1975-1985. https://doi.org/10.1017/S1751731116001245.

Doepel, L., and H. Lapierre. 2011. Deletion of arginine from an abomasal infusion of amino acids does not decrease milk protein yield in Holstein cows. J. Dairy Sci. 94:864-873. https://doi.org/10.3168/ jds.2010-3497.

Doepel, L., M. Lessard, N. Gagnon, G. Lobley, J. Bernier, P. Dubreuil, and H. Lapierre. 2006. Effect of postruminal glutamine supplementation on immune response and milk production in dairy cows. J. Dairy Sci. 89:3107-3121. https://doi.org/10.3168/jds.S0022 -0302(06)72585-1.

Doepel, L., G. Lobley, J. Bernier, P. Dubreuil, and H. Lapierre. 2009. Differences in splanchnic metabolism between late gestation and early lactation dairy cows. J. Dairy Sci. 92:3233-3243. https://doi .org/10.3168/jds.2008-1595.

Doepel, L., G. E. Lobley, J. F. Bernier, P. Dubreuil, and H. Lapierre. 2007. Effect of glutamine supplementation on splanchnic metabolism in lactating dairy cows. J. Dairy Sci. 90:4325-4333. https:// doi.org/10.3168/jds.2007-0124.

Doepel, L., D. Pacheco, J. Kennelly, M. Hanigan, I. Lopez, and H. Lapierre. 2004. Milk protein synthesis as a function of amino acid supply. J. Dairy Sci. 87:1279-1297. https://doi.org/10.3168/jds .S0022-0302(04)73278-6.

El-Kadi, S. W., R. L. Baldwin, N. E. Sunny, S. L. Owens, and B. J. Bequette. 2006. Intestinal protein supply alters amino acid, but not glucose, metabolism by the sheep gastrointestinal tract. J. Nutr. 136:1261-1269. https://doi.org/10.1093/jn/136.5.1261.

Farrell, H., Jr., R. Jimenez-Flores, G. Bleck, E. Brown, J. Butler, L. Creamer, C. Hicks, C. Hollar, K. Ng-Kwai-Hang, and H. Swaisgood. 2004. Nomenclature of the proteins of cows' milk-Sixth revision. J. Dairy Sci. 87:1641-1674. https://doi.org/10.3168/jds .S0022-0302(04)73319-6. 
Galindo, C., D. R. Ouellet, D. Pellerin, S. Lemosquet, I. OrtiguesMarty, and H. Lapierre. 2011. Effect of amino acid or casein supply on whole-body, splanchnic, and mammary glucose kinetics in lactating dairy cows. J. Dairy Sci. 94:5558-5568. https://doi.org/ 10.3168/jds.2010-3978.

Gressley, T. F., S. M. Reynal, J. J. O. Colmenero, G. A. Broderick, and L. E. Armentano. 2006. Technical note: Development of a tool to insert abomasal infusion lines into dairy cows. J. Dairy Sci. 89:3965-3967. https://doi.org/10.3168/jds.S0022-0302(06)72438 $-9$.

Hanigan, M., J. Cant, D. Weakley, and J. Beckett. 1998. An evaluation of postabsorptive protein and amino acid metabolism in the lactating dairy cow. J. Dairy Sci. 81:3385-3401. https://doi.org/10 .3168/jds.S0022-0302(98)75903-X.

Hanigan, M., C. Reynolds, D. Humphries, B. Lupoli, and J. Sutton. 2004. A model of net amino acid absorption and utilization by the portal-drained viscera of the lactating dairy cow. J. Dairy Sci. 87:4247-4268. https://doi.org/10.3168/jds.S0022-0302(04)73570 $-5$.

Hanigan, M. D. 2005. Quantitative aspects of ruminant splanchnic metabolism as related to predicting animal performance. Anim. Sci. 80:23-32. https://doi.org/10.1079/ASC40920023.

Haque, M. N., J. Guinard-Flament, P. Lamberton, C. Mustiere, and S. Lemosquet. 2015. Changes in mammary metabolism in response to the provision of an ideal amino acid profile at 2 levels of metabolizable protein supply in dairy cows: Consequences on efficiency. J. Dairy Sci. 98:3951-3968. https://doi.org/10.3168/jds.2014-8656.

Haque, M. N., H. Rulquin, A. Andrade, P. Faverdin, J. L. Peyraud, and S. Lemosquet. 2012. Milk protein synthesis in response to the provision of an "ideal" amino acid profile at 2 levels of metabolizable protein supply in dairy cows. J. Dairy Sci. 95:5876-5887. https://doi.org/10.3168/jds.2011-5230.

Huhtanen, P., A. Vanhatalo, and T. Varvikko. 2002. Effects of abomasal infusions of histidine, glucose, and leucine on milk production and plasma metabolites of dairy cows fed grass silage diets. J. Dairy Sci. 85:204-216.

Huntington, G. B. 1984. Net absorption of glucose and nitrogenous compounds by lactating Holstein cows. J. Dairy Sci. 67:1919-1927. https://doi.org/10.3168/jds.S0022-0302(84)81525-8.

Huntington, G. B., C. K. Reynolds, and B. H. Stroud. 1989. Techniques for measuring blood flow in splanchnic tissues of cattle. J. Dairy Sci. 72:1583-1595. https://doi.org/10.3168/jds.S0022 $-0302(89) 79270-5$

INRA (Institut National de la Recherche Agronomique). 2018. INRA Feeding System for Ruminants. Wageningen Academic Publishers, Wageningen, the Netherlands.

Karman, A. H., and A. J. S. van Boekel. 1986. Evaluation of the Kjeldahl factor for conversion of the nitrogen content of milk and milk products to protein content. Neth. Milk Dairy J. 40:315-336.

Lapierre, H., R. Berthiaume, G. Raggio, M. C. Thivierge, L. Doepel, D. Pacheco, P. Dubreuil, and G. E. Lobley. 2005. The route of absorbed nitrogen into milk protein. Anim. Sci. 80:11-22. https:// doi.org/10.1079/ASC41330011.

Lapierre, H., S. Binggeli, M. Sok, D. Pellerin, and D. R. Ouellet. 2019. Estimation of correction factors to determine the true amino acid concentration of protein after a 24-hour hydrolysis. J. Dairy Sci. 102:1205-1212. https://doi.org/10.3168/jds.2018-15392.

Lapierre, H., J. Blouin, J. Bernier, C. Reynolds, P. Dubreuil, and G. Lobley. 2002. Effect of supply of metabolizable protein on whole body and splanchnic leucine metabolism in lactating dairy cows. J. Dairy Sci. 85:2631-2641. https://doi.org/10.3168/jds.S0022 -0302(02)74348-8.

Lapierre, H., C. E. Galindo, S. Lemosquet, I. Ortigues-Marty, L. Doepel, and D. R. Ouellet. 2010. Protein supply, glucose kinetics and milk yield in dairy cows. Pages 277-288 in Energy and Protein Metabolism and Nutrition. EAAP Publication No. 127. C. M. Crovetto, ed. Wageningen Acad. Publ., Wageningen, the Netherlands.

Lapierre, H., M. Hanigan, and D. R. Ouellet. 2016. Estimation of duodenal endogenous protein flow in dairy cattle: A regression approach. Pages 131-132 in Proc. Energy Protein Metab. Nutr. Wageningen Acad. Publ., Wageningen, the Netherlands.
Lapierre, H., G. E. Lobley, L. Doepel, G. Raggio, H. Rulquin, and S. Lemosquet. 2012. Triennial lactation symposium: Mammary metabolism of amino acids in dairy cows. J. Anim. Sci. 90:1708-1721.

Lapierre, H., R. Martineau, M. D. Hanigan, H. J. van Lingen, E. Kebreab, J. W. Spek, and D. R. Ouellet. 2020. Review: Impact of protein and energy supply on the fate of amino acids from absorption to milk protein in dairy cows. Animal (Accepted).

Larsen, M., C. Galindo, D. R. Ouellet, G. Maxin, N. Kristensen, and H. Lapierre. 2015. Abomasal amino acid infusion in postpartum dairy cows: Effect on whole-body, splanchnic, and mammary amino acid metabolism. J. Dairy Sci. 98:7944-7961. https://doi.org/ 10.3168/jds.2015-9439.

Lee, C., F. Giallongo, A. Hristov, H. Lapierre, T. Cassidy, K. Heyler, G. Varga, and C. Parys. 2015. Effect of dietary protein level and rumen-protected amino acid supplementation on amino acid utilization for milk protein in lactating dairy cows. J. Dairy Sci. 98:1885-1902. https://doi.org/10.3168/jds.2014-8496.

Lee, C., A. N. Hristov, K. S. Heyler, T. W. Cassidy, H. Lapierre, G. A. Varga, and C. Parys. 2012. Effects of metabolizable protein supply and amino acid supplementation on nitrogen utilization, milk production, and ammonia emissions from manure in dairy cows. J. Dairy Sci. 95:5253-5268. https://doi.org/10.3168/jds.2012-5366.

Lemosquet, S., J. Guinard-Flament, G. Raggio, C. Hurtaud, J. Van Milgen, and H. Lapierre. 2010a. How does increasing protein supply or glucogenic nutrients modify mammary metabolism in lactating dairy cows? Pages $175-186$ in Energy and Protein Metabolism and Nutrition. Wageningen Acad. Publ., Wageningen, the Netherlands.

Lemosquet, S., G. Lobley, R. Koopman, L. Van Loon, A. Kies, H. Lapierre, and C. Crovetto. 2010b. A large supply of phenylalanine is not oxidised by the mammary gland of dairy cows. Pages 137-138 in EAAP Int. Symp. Energy Protein Metab. Nutr. Wageningen Acad. Publ., Wageningen, the Netherlands.

Lobley, G. 1990. Energy metabolism reactions in ruminant muscle: Responses to age, nutrition and hormonal status. Reprod. Nutr. Dev. 30:13-34. https://doi.org/10.1051/rnd:19900102.

Lobley, G., A. Connell, M. A. Lomax, D. S. Brown, E. Milne, A. G. Calder, and D. Farningham. 1995. Hepatic detoxification of ammonia in the ovine liver: Possible consequences for amino acid catabolism. Br. J. Nutr. 73:667-685. https://doi.org/10.1079/ bjn19950072.

Lobley, G. E., and H. Lapierre. 2003. Post-absorptive metabolism of amino acids. Pages 737-756 in Progress in Research on Energy and Protein Metabolism. W. B. Souffrant and C. C. Metges, ed. Wageningen Acad. Publ., Wageningen, the Netherlands.

Martineau, R., C. Benchaar, H. V. Petit, H. Lapierre, D. R. Ouellet, D. Pellerin, and R. Berthiaume. 2007. Effects of lasalocid or monensin supplementation on digestion, ruminal fermentation, blood metabolites, and milk production of lactating dairy cows. J. Dairy Sci. 90:5714-5725. https://doi.org/10.3168/jds.2007-0368.

Martineau, R., D. R. Ouellet, E. Kebreab, R. White, and H. Lapierre. 2017. Relationships between postruminal casein infusion and milk production, and concentrations of plasma amino acids and blood urea in dairy cows: A multilevel mixed-effects meta-analysis. J. Dairy Sci. 100:8053-8071. https://doi.org/10.3168/jds.2016-11813.

Mepham, T. B. 1982. Amino acid utilization by lactating mammary gland. J. Dairy Sci. 65:287-298.

Metcalf, J., R. Mansbridge, J. Blake, J. Oldham, and J. Newbold. 2008. The efficiency of conversion of metabolisable protein into milk true protein over a range of metabolisable protein intakes. Animal 2:1193-1202. https://doi.org/10.1017/S1751731108002140.

Nichols, K., J. J. M. Kim, M. Carson, J. A. Metcalf, J. P. Cant, and J. Doelman. 2016. Glucose supplementation stimulates peripheral branched-chain amino acid catabolism in lactating dairy cows during essential amino acid infusions. J. Dairy Sci. 99:1145-1160. https://doi.org/10.3168/jds.2015-9912.

Nichols, K., H. van Laar, A. Bannink, and J. Dijkstra. 2019. Mammary gland utilization of amino acids and energy metabolites differs when dairy cow rations are isoenergetically supplemented with protein and fat. J. Dairy Sci. 102:1160-1175. https://doi.org/10 $.3168 /$ jds.2018-15125. 
NRC. 2001. Nutrient Requirements of Dairy Cattle. 7th rev. ed. Natl. Acad. Press, Washington, DC.

Omphalius, C., H. Lapierre, J. Guinard-Flament, P. Lamberton, L. Bahloul, and S. Lemosquet. 2019. Amino acid efficiencies of utilization vary by different mechanisms in response to energy and protein supplies in dairy cows: Study at mammary gland and whole-body levels. J. Dairy Sci. 102:9883-9901. https://doi.org/ 10.3168/jds.2019-16433.

Raggio, G., S. Lemosquet, G. Lobley, H. Rulquin, and H. Lapierre. 2006a. Effect of casein and propionate supply on mammary protein metabolism in lactating dairy cows. J. Dairy Sci. 89:43404351. https://doi.org/10.3168/jds.S0022-0302(06)72481-X.

Raggio, G., G. Lobley, S. Lemosquet, H. Rulquin, and H. Lapierre. 2006b. Effect of casein and propionate supply on whole body protein metabolism in lactating dairy cows. Can. J. Anim. Sci. 86:8189. https://doi.org/10.4141/A05-055.

Raggio, G., G. E. Lobley, R. Berthiaume, D. Pellerin, G. Allard, P. Dubreuil, and H. Lapierre. 2007. Effect of protein supply on hepatic synthesis of plasma and constitutive proteins in lactating dairy cows. J. Dairy Sci. 90:352-359. https://doi.org/10.3168/jds .S0022-0302(07)72636-X.

Raggio, G., D. Pacheco, R. Berthiaume, G. Lobley, D. Pellerin, G. Allard, P. Dubreuil, and H. Lapierre. 2004. Effect of level of metabolizable protein on splanchnic flux of amino acids in lactating dairy cows. J. Dairy Sci. 87:3461-3472. https://doi.org/10.3168/ jds.S0022-0302(04)73481-5.

Reynolds, C. 2006. Splanchnic amino acid metabolism in ruminants. Pages 225-248 in Ruminant Physiology: Digestion, Metabolism and Impact of Nutrition on Gene Expression, Immunology and Stress. K. Sejrsen, T. Hvelplund, and M. O. Nielsen, ed. Wageningen Acad. Publ., Wageningen, the Netherlands.

Rius, A., J. Appuhamy, J. Cyriac, D. Kirovski, O. Becvar, J. Escobar, M. McGilliard, B. Bequette, R. Akers, and M. Hanigan. 2010a. Regulation of protein synthesis in mammary glands of lactating dairy cows by starch and amino acids. J. Dairy Sci. 93:3114-3127. https://doi.org/10.3168/jds.2009-2743.

Rius, A., M. McGilliard, C. Umberger, and M. Hanigan. 2010b. Interactions of energy and predicted metabolizable protein in determining nitrogen efficiency in the lactating dairy cow. J. Dairy Sci. 93:2034-2043. https://doi.org/10.3168/jds.2008-1777.

Rulquin, H., S. Rigout, S. Lemosquet, and A. Bach. 2004. Infusion of glucose directs circulating amino acids to the mammary gland in well-fed dairy cows. J. Dairy Sci. 87:340-349. https://doi.org/10 .3168/jds.S0022-0302(04)73173-2.

Vanhatalo, A., T. Varvikko, and P. Huhtanen. 2003. Effects of casein and glucose on responses of cows fed diets based on restrictively fermented grass silage. J. Dairy Sci. 86:3260-3270. https://doi .org/10.3168/jds.S0022-0302(03)73929-0.

Windmueller, H. G., and A. E. Spaeth. 1974. Uptake and metabolism of plasma glutamine by the small intestine. J. Biol. Chem. 249:5070-5079

Wolff, J., and E. Bergman. 1972. Metabolism and interconversions of five plasma amino acids by tissues of the sheep. Am. J. Physiol. 223:447-454. https://doi.org/10.1152/ajplegacy.1972.223.2.447. 